\title{
Stn1, a new Saccharomyces cerevisiae protein, is implicated in telomere size regulation in association with $\mathrm{Cdc13}$
}

\author{
Nathalie Grandin, ${ }^{1-3}$ Steven I. Reed, ${ }^{2}$ and Michel Charbonneau ${ }^{1,4}$ \\ ${ }^{1}$ Yeast Cell Cycle Group, Unité Mixte de Recherche Centre National de la Recherche Scientifique/Ecole Normale \\ Supérieure (UMR CNRS/ENS), no. 49, 69364 Lyon, France; ${ }^{2}$ Department of Molecular Biology, Scripps Research Institute, \\ La Jolla, California 92037 USA
}

We have isolated STN1, an essential Saccharomyces cerevisiae gene, as a suppressor of the cdc13-1 mutation. A synthetic lethal interaction between a temperature-sensitive mutant allele of $S T N 1$, stn1-13, and $c d c 13-1$ was observed. Stn1 and Cdc13 proteins displayed a physical interaction by two-hybrid analysis. As shown previously for $c d c 13-1, \operatorname{stn1-13}$ cells at the restrictive temperature accumulate single-stranded DNA in subtelomeric regions of the chromosomes, but to a lesser extent than cdc13-1 cells. In addition, both Cdc13 and Stn1 were found to be involved in the regulation of telomere length, mutations in STN1 or CDC13 conferring an increase in telomere size. Loss of $S \operatorname{tn} 1$ function activated the $R A D 9$ and $M E C 3 \mathrm{G}_{2} / \mathrm{M}$ checkpoints, therefore confirming that DNA damage is generated. We propose that Stn1 functions in telomere metabolism during late $S$ phase in cooperation with Cdc13.

[Key Words: Stn1; Cdc13; telomeres; mitotic checkpoints; S phase; yeast cell cycle]

Received August 30, 1996; revised version accepted December 18, 1996.

Telomeres are specialized structures at the ends of eukaryotic chromosomes that are necessary for maintaining chromosomal integrity (for review, see Gilson et al. 1993; Greider 1995; Zakian 1995a,b). One of the essential functions of telomeres is to protect chromosome ends from end-to-end fusions and degradation (McClintock 1941; Sandell and Zakian 1993). Another essential function of telomeres is to provide a mechanism for the replication of chromosome ends, a mechanism that requires a specialized enzyme, telomerase, therefore preventing a progressive shortening and degradation of the chromosomes (for review, see Greider 1995; Zakian 1995b|. Telomeres also have nonessential functions, such as to repress the transcription of adjacent genes and to affect the timing of nearby DNA replication origins (Gottschling et al. 1990; Ferguson and Fangman 1992; Brewer et al. 1993; for review, see Sandell and Zakian 1992). Telomeres associate with one another, assembling unusual chromatin structures, called telosomes, which probably have a role in regulation of transcription in these regions (for review, see Gilson et al. 1993; Gilson and Gasser 1995).

The telomeric DNA of almost all eukaryotic cells is composed of short repeat sequences, which in Saccharo-

\footnotetext{
${ }^{3}$ Present address: Yeast Cell Cycle Group, UMR CNRS/ENS no. 49, Ecole Normale Supérieure de Lyon, Lyon, France.

${ }^{4}$ Corresponding author.

E-MAIL Michel.Charbonneau@ens-lyon.fr; FAX (33) 472728686.
}

myces cerevisiae are heterogeneous $\mathrm{C}_{1-3} \mathrm{~A} / \mathrm{TG}_{1-3}$ repeats $\sim 300 \mathrm{bp}$ long. Telomere length is thought to be the result of a complex balance between processes that lead to their degradation and processes that lengthen them (for review, see Zakian 1995b). The $300 \mathrm{bp}$-long $\mathrm{C}_{1_{-3}} \mathrm{~A}$ / $\mathrm{TG}_{1-3}$ telomeric sequences of $S$. cerevisiae are thought to be necessary and sufficient for all essential functions of telomeres. $\mathrm{TG}_{1-3}$ tails are overhangs of the telomeric G-rich strand that represent natural intermediates during telomere replication forming at the end of $S$ phase (Wellinger et al. 1992). In addition to serving as a substrate for telomere repeat addition by telomerase and therefore G-rich strand elongation, $\mathrm{TG}_{1-3}$ tails are thought to serve as a substrate for putative telomerebinding proteins (McEachern and Blackburn 1995; for review, see Zakian 1995b). However, $\mathrm{TG}_{1-3}$ tails were found to be present on telomeres in strains lacking telomerase. Moreover, in vivo-generated DNA molecules were found to have $\mathrm{TG}_{1-3}$ tails at both ends, a situation incompatible with the existence of a sole telomerase-dependent mechanism of formation of $\mathrm{TG}_{1-3}$ tails (Wellinger et al. 1996). Conventional replication mechanisms and telomerase-mediated strand elongation ultimately yield molecules with the leading strand of synthesis having a blunt end and the other end having a short 3' overhang. This observation, together with the demonstration that $c d c 13$ mutant cells display an increased amount of single-stranded DNA in telomeric and subtelomeric regions of their chromosomes, has led to 
the proposition that a strand-specific exonuclease might generate $\mathrm{TG}_{1-3}$ tails at each telomere (Wellinger et al. 1996) and that cell cycle-controlled degradation of the $\mathrm{C}_{1-3} \mathrm{~A}$ strand might be regulated by Cdc13 /Garvik et al. 1995). Therefore, Cdc13 might limit the extent of exonuclease digestion of the $\mathrm{TG}_{1-3}$ tails or limit their elongation. In agreement with this model, it was shown that mutation of $R A D 24$ in a $c d c 13$ mutant background was sufficient to suppress the generation of extra singlestranded DNA seen in $c d c 13$ single mutants (Lydall and Weinert 1995). Interestingly, Rad24 appears to control Rad17, a putative exonuclease (Lydall and Weinert 1995). In $S$. cerevisiae, RAD24 and RAD17 are part of a complex system of checkpoint control that ensures that cells do not enter mitosis in the presence of damaged or unreplicated DNA by blocking, by an unknown mechanism, cell cycle progression (Weinert and Hartwell 1988, 1993; Weinert et al. 1994). DNA damage generated by mutations in $C D C 13$ or other $\mathrm{S}$ phase genes (such as $C D C 2$, $C D C 8, C D C 9$, or $C D C 17$, for instancel is detected readily by the checkpoint system which, in addition to RAD17 and RAD24, also comprises RAD9, MEC1, RAD53 (MEC2), and MEC3 (Weinert and Hartwell 1988, 1993; Weinert et al. 1994).

In studies on telomeres, the role of $\mathrm{Cdc} 13$ seems to be of particular importance because it is a good candidate not only for controlling the elongation of $\mathrm{TG}_{1-3}$ tails and subsequently telomere maintenance but also for association between telomeres and protection against the $R A D 9$-dependent DNA repair system (Garvik et al. 1995). The CDC13 gene has been cloned, but its sequence has not suggested a biochemical function /Garvik et al. 1995). Recently, Cdcl3 was shown to bind to several single-strand G-rich yeast telomeric oligomers (Nugent et al. 1996). Together with the observations of telomere shortening in $c d c 13-2^{\text {est }}$ mutant cells and of a genetic interaction between $C D C 13$ and EST1, a regulatory component of yeast telomerase, this has led to the proposition that Cdc13 might mediate telomerase loading at the chromosome end (Nugent et al. 1996). Moreover, the absence of an enhanced phenotype in a strain bearing a disruption of TLC1, the telomerase RNA gene, and the $c d c 13-2^{e s t}$ mutation, and, in contrast, the observation of an enhancement of the senescence phenotype associated with telomere shortening in the $c d c 13-1 \Delta t l c 1$ double mutant suggested a dual role for $\mathrm{Cdc} 13$ in telomere maintenance (Nugent et al. 1996). One function of Cdc13, lost in the $c d c 13-2^{\text {est }}$ mutant, would be to positively regulate telomerase activity by mediating its access to the telomeric G-rich extension. A second function of Cdc13, lost in the cdc13-1 mutant, would be to protect the chromosome end from degradation (Garvik et al. 1995; Nugent et al. 1996).

In this context, studies on Cdc13-dependent pathways are fundamental for understanding telomere metabolism and its relationship to the cell cycle. We report here the isolation of a novel, essential, gene of $S$. cerevisiae, STN1, as a suppressor of the $c d c 13-1$ mutation. We show that both $c d c 13-1$ and $\operatorname{stn} 1-13$ loss-of-function mutants exhibit a defect in telomere size regulation that leads to a dramatic elongation of telomeres. These mutants were also found to accumulate increased amounts of singlestranded DNA in subtelomeric regions of their chromosomes. Finally, Cdc13 and Stn 1 scored positive for interaction by two-hybrid analysis, suggesting that they form a complex in vivo. Based on these findings, we propose a model in which $\mathrm{Cdcl} 3$ is a dual regulator (alternatively, a positive and a negative regulator) of telomerase activity. We further propose that Stn 1 acts as an inhibitor of telomerase loading through its interaction with Cdc13. In our model, Cdc13 mediates access of the telomerase complex, Tlc1/Est1, to the chromosome end but also mediates access of Stn 1 for activation of its inhibitory activity) to this complex, resulting in turning off of telomerase activity.

\section{Results}

\section{Isolation of STN1}

At the restrictive temperature of $37^{\circ} \mathrm{C}, c d c 13-1$ mutants arrest in $\mathrm{G}_{2}$. At the semi-permissive temperature of $30^{\circ} \mathrm{C}, c d c 13-1$ mutants grow very slowly, reflecting partial activation of the RAD9-dependent checkpoint. This checkpoint is thought to allow repair of $c d c 13$-induced chromosomal damage before progression through mitosis (Weinert and Hartwell 1993; Garvik et al. 1995). Under such conditions, genomic DNA fragments from a low-copy plasmid bank capable of suppressing the cdc13-1 mutation could potentially identify proteins interacting specifically with Cdc13.

Strain cdc13-1 was transformed with a $S$. cerevisiae genomic DNA library constructed in YCp50 (Rose et al. 1987) and $\sim 60,000$ transformants were screened for their ability to complement the slow growth phenotype of cdc13-1 cells at $30^{\circ} \mathrm{C}$ and inability to restore complete growth at $37^{\circ} \mathrm{C}$ (to avoid re-isolation of $C D C 13$ ). Two colonies were isolated and their plasmids recovered. Partial restriction mapping demonstrated that both were identical, bearing the same $7-\mathrm{kb}$ insert. Subcloning revealed that a $3.5-\mathrm{kb}$ DNA fragment containing a single 1.7-kb-long open reading frame (ORF) with no apparent intronic sequences was capable of suppressing the cdc13-1 mutation (data not shown). This gene was named STN1, for suppressor of $c d c$ thirteen. A search of the compiled data bases using the BLAST program at the National Center for Biotechnology Information (NCBI), National Institutes of Health (NIH), revealed that the sequenced ORF was a novel gene exhibiting no homology with any known protein or gene and no consensus sequences with previously identified motifs. After the STN1 gene was sequenced, a DNA sequence identical to STN1 appeared in the data banks as a result of the automated sequencing program of chromosome IV, which corresponded to ORF YDR082w, gene D4456.

To confirm the structure of the STN1 gene, its cDNA was isolated following transformation with a $S$. cerevisiae cDNA library (see Materials and Methods) of a strain in which the STN1 gene had been disrupted and that was kept alive by the presence of an STN1-URA3 
plasmid that was subsequently shuffled out on 5-FOA medium (see below; see also Materials and Methods). Sequencing of this cDNA confirmed the primary structure of the STN1 coding sequence, in particular the identity of the initiating ATG and terminating stop codons and confirmed the absence of introns in the genomic DNA (data not shown).

\section{STN1 is an essential gene}

A diploid yeast strain was transformed with a DNA fragment containing the STN1 ORF interrupted by the TRP1 gene from the ATG to the EcoRI site at position 842, leaving 642 nucleotides downstream, as described in Materials and Methods. Sporulation and tetrad analysis of this heterozygous (STN1/stn1::TRP1) diploid strain showed that only two of the four spores per tetrad were viable at $30^{\circ} \mathrm{C}$ on YEPD (in all 52 tetrads dissected). All viable spores were $\mathrm{Trp}^{-}$, indicating that the inviable spores contained the stn1::TRP1 replacement. Microscopic examination indicated that mutant spores, in which the STN1 gene had been disnupted, germinated, and completed one to three rounds of division before arresting with a nonuniform phenotype /data not shown). Actual disruption of STN1 was verified by PCR and Southern analysis. Re-introduction of STN1 on a centromeric plasmid restored viability to the $\operatorname{stn} 1$ disrupted strain (data not shown). Another STN1 disruption was constructed by replacing nucleotides 1-559 with the URA3 locus (see Materials and Methods). Sporulation of the $\sin 1:: U R A 3 / S T N 1$ diploid gave a $2:: 2$ viability, all viable spores being $\mathrm{Ura}^{-}$. Therefore, wild-type $S$. cerevisiae cells are incapable of growth in the absence of the STN1 gene and arrest following spore germination with a nonhomogeneous morphology.

Suppression by overexpression of STN1 is specific for the $\mathrm{cdc} 13$ mutation

Suppression of $c d c 13-1$ by YCp50-STN1 did not occur at $32^{\circ} \mathrm{C}$ or higher temperatures (data not shown). However, when STN1 was maintained in the cell carried on a YEp (high copy) plasmid, rescue of $c d c 13-1$ was observed at $32^{\circ} \mathrm{C}$, but not higher (data not shown). Finally, STN1 expressed from a YCp-GAL plasmid (a centromeric plasmid in which the STN1 gene was cloned behind the strong inducible GAL1 promoter) could rescue the $c d c 13$ mutation at $34^{\circ} \mathrm{C}$, but not higher (Fig. 1). Therefore, overexpression of STN1 cannot totally bypass the CDC13 function, suggesting that $\operatorname{Stn} l$ is not simply a downstream element in the $\mathrm{Cdc} 13$ pathway.

To assess the specificity of $c d c 13$ suppression, strains bearing mutations in CDC2 (DNA polymerase III; Boulet et al. 1989), $C D C 9$ (DNA ligase; Johnston and Nasmyth 1978 ), or CDC17 (a structural subunit of DNA polymerase $\alpha$; Carson and Hartwell 1985) were transformed with YEp-GAL-STN1. None of the defects conferred by these mutations was rescued by overexpressed STN1 (data not shown).

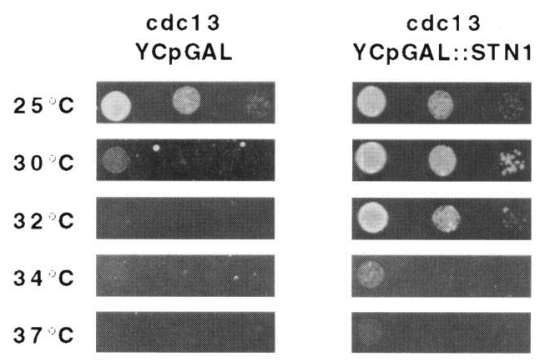

Figure 1. Suppression of the temperature-sensitive growth phenotype of the $c d c 13-1$ mutation by overexpression of STN1. YNG32 (cdc13-1) was transformed with YCp111-GAL (left) or YCp111-GAL-STN1 (right) and 10-fold serial dilutions (from left to right in each row) of a representative transformant grown for 2 days at the indicated temperatures on galactose-based medium are shown.

\section{Analysis of Stn1 depletion and of the stn1-13 mutation}

Initially, before a temperature-sensitive mutant of STN1 was available, we used the $\sin 1:: T R P 1$ disruptant that was kept alive owing to a YCp-GAL-STN1 (URA3) plasmid. Shifting such cells from galactose to glucose medium resulted in progressive exhaustion of Stnl. Under these conditions, it was not until after 1 to 2 days, a delay presumably necessary for total depletion of intracellular stores of previously accumulated Stnl protein, that a defect in cell growth was observed. Cells became very large and appeared to arrest with a large bud (Fig. 2A). However, some cells continued to grow very slowly (Fig. 2A). Because the GAL1 promoter is tightly repressed by glucose, we interpreted this result as indicating that some endogenous promoter-like sequences in the coding region of the STN1 gene were driving its expression independently of the GAL1 promoter. To verify this hypothesis, the $\operatorname{stn} 1:: T R P 1 \mathrm{YCp}-\mathrm{GAL}-\mathrm{STN} 1-\mathrm{URA} 3$ strain was transformed with a YCp-LEU2 (promoterless) plasmid carrying STN1 ORF without any endogenous promoter sequences, and the transformed cells forced to loose the YCp-GAL-STN1-URA3 plasmid on 5-FOA medium. The appearance of $\mathrm{Ura}^{-}$colonies indicated that expression of the STN1 gene could be driven by putative promoter-like sequences within the coding region of the gene or cryptic promoter-like sequences in the vector. Under such conditions, however, expression of STN1 was at a lower level than when driven by the real, physiological promoter, as growth was impaired seriously (data not shown). In the absence of the YCp-STN1-LEU2 plasmid, the $\operatorname{stn} 1:: T R P 1$ YCp-GAL-STN1-URA3 strain was incapable of forming colonies on 5-FOA glucosebased medium, which confirmed that in the previous experiment the STN1 ORF alone without its promoter was responsible for the growth of the STN1 disruptant strain (data not shown).

A temperature-sensitive mutation of STN1 was isolated using PCR under mutagenic conditions. The mutagenized PCR products were then transformed into a STN1 disruptant strain containing a YCp-GAL-STN1- 
A

stn1::TRP1 YCpG-STN1 on glucose

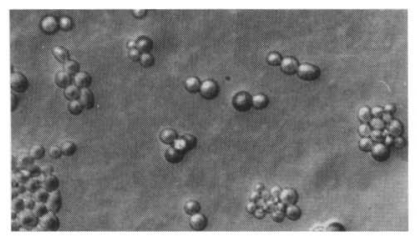

C

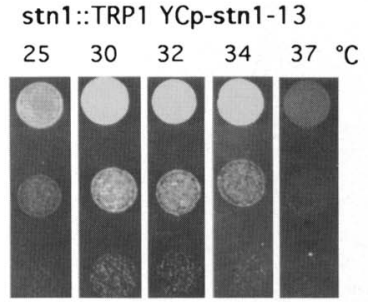

B
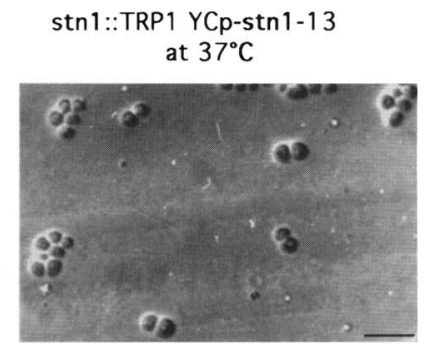

D

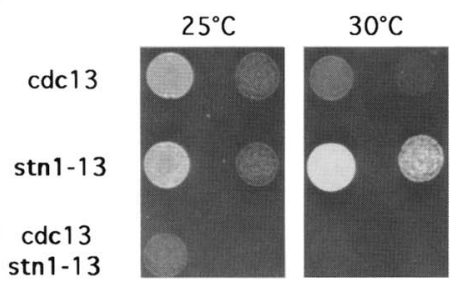

Figure 2. (A) Arrest phenotype of Stn1-depleted cells. Strain YNG346 bearing a disruption of STN1 and kept alive owing to the presence of a plasmid containing STN1 under the control of the GAL1 promoter was grown on a galactose plate. Cells were then streaked onto a glucose plate. After $48 \mathrm{hr}$ on glucose, most cells have become arrested with large buds. Other cells continue to grow very slowly on glucose because of the presence of promoter-like sequences in the STN1 ORF (see text). (B) Strain YNG429, disrupted for STN1, and containing a temperature-sensitive allele of STN1, stn1-13, displays a severe growth defect, visible here after $6 \mathrm{hr}$ at $37^{\circ} \mathrm{C}$ on a plate, with large-budded cells accumulating. The appearance of slow-growing colonies most probably corresponds to leakiness of the mutation. Bar, $10 \mu \mathrm{m}$. (C) The three rows represent 10 -fold serial dilutions of cells from strain YNG429 which were grown overnight at the indicated temperatures. $(D)$ stn1-13 and $c d c 13-1$ mutations are synthetically lethal. Spores bearing both the $c d c 13-1$ and $s t n 1-13$ mutations $($ see text for explanations| grew only very slowly at $25^{\circ} \mathrm{C}$, and stopped dividing completely at $30^{\circ} \mathrm{C}$, whereas singly mutant cells were capable of proliferation at $30^{\circ} \mathrm{C}$. The two patches of cells in each row represent 10 -fold serial dilutions of the same culture.

URA3 plasmid, together with a linear YCp-LEU2 plasmid bearing STN1 flanking regions at its extremities, a process known as the gap repair method (see Materials and Methods). After loss of the STN1-URA3 plasmid on 5-FOA, one temperature-sensitive allele of STN1, stn113 , was selected. We do not know yet whether the stn113 phenotype corresponds to one or several mutations. Although $\operatorname{stn} 1-13$ cells could grow well at temperatures between $25^{\circ} \mathrm{C}$ and $32^{\circ} \mathrm{C}$, they grew slowly at $34^{\circ} \mathrm{C}$ and displayed a severe growth defect at $37^{\circ} \mathrm{C}$ (Fig. $2 \mathrm{~B}, \mathrm{C}$ ). The appearance of colonies after several days at $37^{\circ} \mathrm{C}$ indicated that the $\sin 1-13$ mutation was conferring a severe growth defect rather than a total growth arrest (Fig. 2B). We noted that all cells were growing very slowly at $37^{\circ} \mathrm{C}$, although to varying degrees, and that, clearly, formation of colonies was not attributable to a reversion of the mutation in some cells. It is therefore probable that the $\operatorname{stn} 1-13$ mutation is somewhat leaky.

To more precisely determine the arrest point of the stn1-13 mutant, cultures were first synchronized with the antimicrotubule agent, nocodazole, and then released at the restrictive temperature; cell cycle progression was monitored at subsequent intervals. In both controls and $\operatorname{stn} 1-13$ mutant cells at $30^{\circ} \mathrm{C}$ as well as at $37^{\circ} \mathrm{C}$, release from the nocodazole block was followed within $30-45 \mathrm{~min}$ by a rapid drop in the percentage of cells with large buds that indicated exit from $M$ phase accompanied by separation of mother and daughter cells (Fig. 3A). This demonstrated that the STN1 execution point is located before the nocodazole block point which, in $S$. cerevisiae, is in late $G_{2}$ or at the $G_{2} / M$ transition (Jacobs et al. 1988). To establish whether this arrest occurred before or after the completion of $S$ phase, cells were blocked in $S$ phase with hydroxyurea. Both wild-type cells at either temperature and $\operatorname{stn} 1-13$ at their permissive temperature of $30^{\circ} \mathrm{C}$ exited mitosis synchronously starting at $\sim 85 \mathrm{~min}$ after release from the S-phase block (Fig. 3B). On the other hand, at the restrictive temperature of $37^{\circ} \mathrm{C}$, stn 1 13 cells remained in $S$ or $G_{2}$ and did not enter into a new cell cycle.

We conclude from both the nocodazole and hydroxyurea experiments that the $\sin 1-13$ mutation arrests cells during late $S$ phase or during $G_{2}$ before the nocodazolesensitive step. Immunofluorescence of microtubules demonstrated that both $\operatorname{stn} 1-13$ and $c d c 13-1$ mutants displayed an arrest phenotype characterized by the presence of a mitotic spindle of medium size, typical of $G_{2}$ arrest (Fig. 3C).

\section{Synthetic lethal interaction between cdc13-1 and $\operatorname{stn} 1-13$}

Given that STN1 had been isolated as a suppressor of the cdc13-1 mutation, we looked for additional genetic interactions between STN1 and CDC13. A strain containing the $c d c 13-1$ mutation was crossed with the strain containing both a disruption of STN1 (TRP1 marker) and the ts $\operatorname{stn} 1$ mutation on a YCp-LEU2 plasmid. In tetrads in which two of the four spores grew normally at $37^{\circ} \mathrm{C}$, we assumed that the wild-type CDC13 and STN1 genes had cosegregated. In such tetrads, the two normally growing spores were found to be $\operatorname{Trp}^{-}$, and therefore the two spores that could not grow at $37^{\circ} \mathrm{C}$ were assumed to contain the $c d c 13-1$ and $\operatorname{stn} 1-13$ mutations. Such spores were found to grow very slowly at $25^{\circ} \mathrm{C}$. At $29^{\circ} \mathrm{C}$, they could not form colonies, whereas $c d c 13-1$ and stn1-13 cells could form colonies at $30^{\circ} \mathrm{C}$ (Fig. 2D). Therefore, 
A
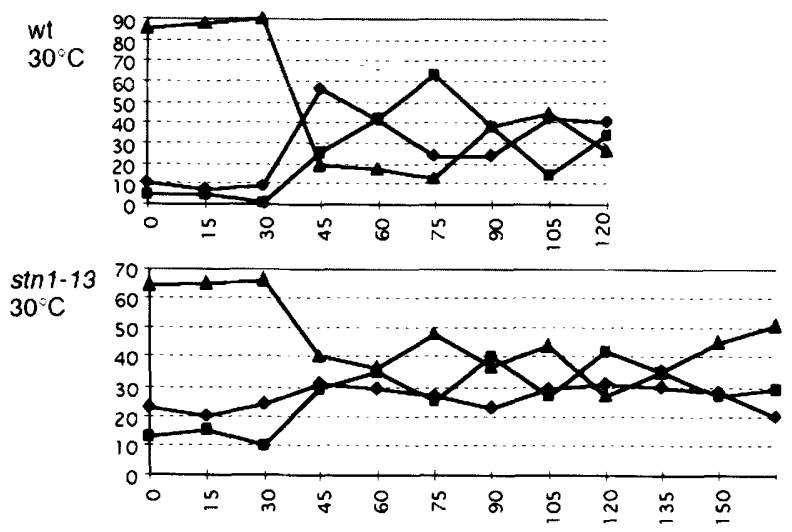

wt
$37^{\circ} \mathrm{C}$
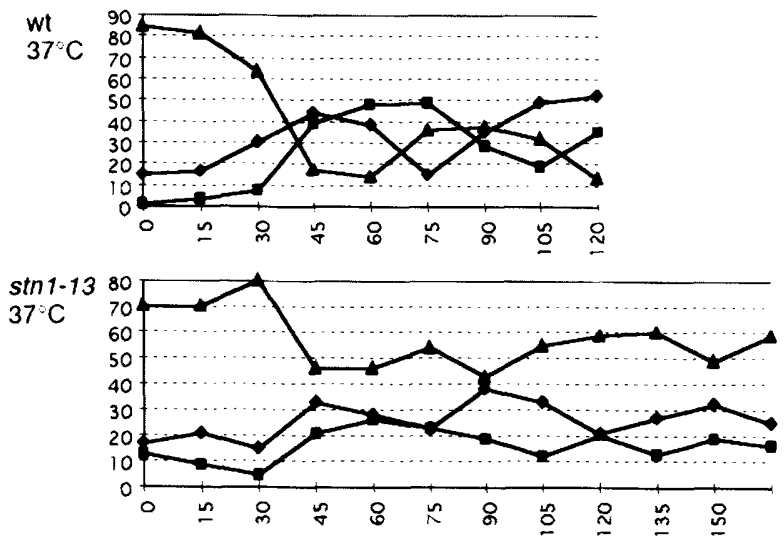

C

DAPI

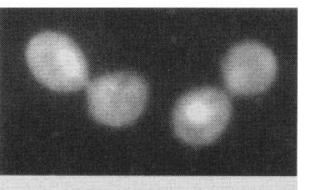

b

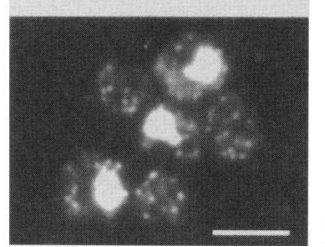

B
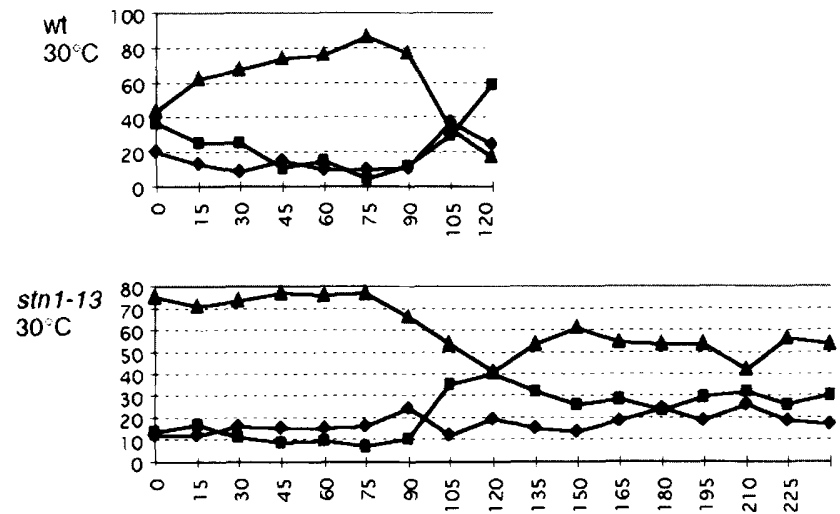

wt

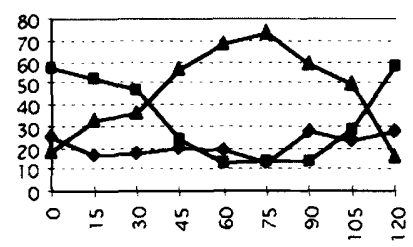

$\operatorname{stn} 1-13$
$37^{\circ} \mathrm{C}$

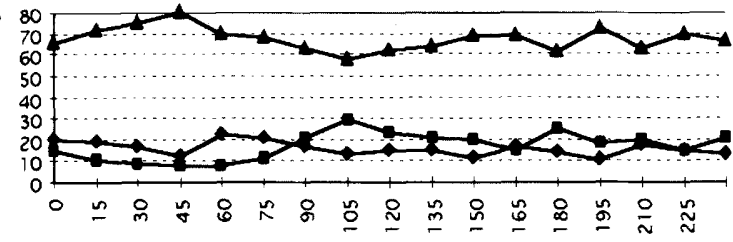

anti tubulin

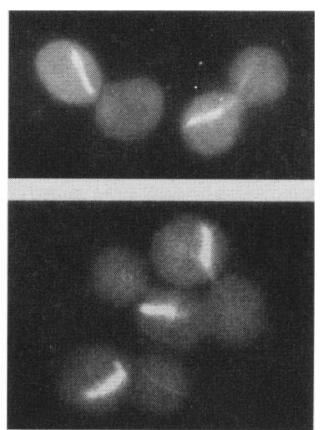

Figure 3. Arrest caused by the $\operatorname{stn} 1-13$ mutation during the cell cycle. $(A)$ Block and release experiments using nocodazole. Log-phase cultures of wild-type (wt) or stn1-13 mutant (strain YNG429) were arrested in the presence of $15 \mu \mathrm{g} / \mathrm{ml}$ of nocodazole (prepared as a stock solution of $10 \mathrm{mg} / \mathrm{ml}$ in DMSO) at $30^{\circ} \mathrm{C}$ for $2 \mathrm{hr}$ and transferred to $30^{\circ} \mathrm{C}$ (top two panels) or $37^{\circ} \mathrm{C}$ (bottom two panels) in the presence of the drug for an additional hour. Removal of the drug by centrifugation, while maintaining cultures at $30^{\circ} \mathrm{C}$ or $37^{\circ} \mathrm{C}$, corresponded to time zero $\left(30^{\circ} \mathrm{C}\right.$ is the optimal temperature of growth for $\operatorname{stn} 1-13$ cells, whereas $37^{\circ} \mathrm{C}$ is a restrictive temperature for $\operatorname{stn} 1-13$ but not for wild-type cells $)$. At 15 -min intervals, aliquots were fixed with formaldehyde and the percentages of unbudded cells $\left(\mathrm{G}_{1}, \bullet \mid\right.$, small and medium buds $\left(S+G_{2}+\right.$ early $\left.M, \mathbf{D}\right)$ and large buds (mid-M + late $\left.M, \Delta\right)$ were determined microscopically. It should be noted that in stn1-13 cells percentages of cell cycle arrest by nocodazole $(A)$ or hydroxyurea $(B)$, at $30^{\circ} \mathrm{C}$ as well as at $37^{\circ} \mathrm{C}$, never reached the $85 \%-90 \%$ level attained by wild-type cells at either temperature, but rather stayed around $65 \%-70 \%$. We believe that, given that the $\operatorname{stn} 1-13$ mutation is deficient in telomere function at all temperatures (see Results corresponding to Fig. 7), it partially activates the DNA damage checkpoint at $30^{\circ} \mathrm{C}$ (a temperature nevertheless permissive for growth, see Fig. 2) that may delay the accumulation of cells at the drug block. Longer exposures to drugs, capable of increasing the percentage of arrested cells, would have had deleterious effects on cell recovery and were therefore not attempted. $(B)$ Block and release experiments using hydroxyurea. Log-phase cultures of wild-type or $\operatorname{stn} 1-13$ cells were treated with $0.4 \mathrm{M}$ hydroxyurea for $2 \mathrm{hr}$ at $30^{\circ} \mathrm{C}$ followed by an hour at $30^{\circ} \mathrm{C}$ (top two panels) or $37^{\circ} \mathrm{C}$ (bottom two panels) before removal of the drug (time zero). Determination of cell cycle stages at 15-min intervals was as in $A$. (C) YNG429 (stn1::TRP1 YCp-stn1-13-LEU2) cells $(a)$ were synchronized with $0.4 \mathrm{M}$ hydroxyurea for $3 \mathrm{hr}$, at $30^{\circ} \mathrm{C}$, then released in the absence of the drug at $37^{\circ} \mathrm{C}$, fixed $2.5 \mathrm{hr}$ later, and processed for tubulin immunofluorescence labeling and staining of the DNA with DAPI (see Materials and Methods). YNG32 (cdc13-1) cells $(b)$, not presynchronized, were incubated at $37^{\circ} \mathrm{C}$ for $5 \mathrm{hr}$ before being processed as described above. 
mutations in the STN1 and CDC13 genes display a synthetic lethal interaction.

A mutation in STN1 or depletion of Stn1 activates the RAD9- and MEC3-dependent mitotic checkpoints

It is known from previous work on $c d c 13-1$ mutants that a failure in $C D C 13$ function does not lead to immediate arrest in $\mathrm{S}$ phase, its presumed execution point, but, instead, activates the $R A D 9$-dependent $\mathrm{G}_{2} / \mathrm{M}$ checkpoint, and that it is the latter constraint that is responsible for the arrest of cdc13 cells (Weinert and Hartwell 1993). Consequently, cells with mutations in both $C D C 13$ and $R A D 9$ fail to exhibit the pause in $\mathrm{G}_{2}$ normally imposed by the $R A D 9$-dependent checkpoint in the presence of DNA damage, such as that caused by the $c d c 13$ mutation. Such cells enter into mitosis inappropriately, leading to cell death after an average of three complete cell division cycles (Garvik et al. 1995). Because of the implication of STN1 in a CDC13-related function, we asked whether a lack of STN1 function in a defective $\mathrm{G}_{2} / \mathrm{M}$ checkpoint background would result in a similar mitotic catastrophe phenotype.

When strain NGY359, bearing a disruption of STN1 (kept alive with YCp-GAL-STN1) and a disruption of $R A D$, was grown on glucose medium, in order to cause a depletion of Stn1, cells no longer accumulated as largebudded cells as did Stn1-depleted $R A D 9^{+}$cells. Rather, they continued to divide and formed microcolonies but rapidly died (data not shown). This phenotype was identical to that observed for $c d c 13$ rad9 double mutants at $37^{\circ} \mathrm{C}$ and is indicative of a mitotic catastrophe phenotype (Weinert et al. 1994; Garvik et al. 1995). In the presence of mec3-2 (N. Grandin and S.I. Reed, unpubl.), a mutation in $M E C 3$, another gene involved in mitotic checkpoint control (Weinert et al. 1994), Stn1-depleted cells also continued to divide and formed microcolonies, therefore failing to undergo the arrest observed in $M E C 3^{+}$ stn1 cells (Fig. 4). Similarly, a stn1::TRP1 stn1-13 mec3-2 double mutant placed at $37^{\circ} \mathrm{C}$ continued to divide actively, forming microcolonies, in contrast to $\operatorname{stn} 1-13$ $M E C 3^{+}$cells, which at $37^{\circ} \mathrm{C}$ exhibited a cell cycle delay (Fig. 4). Moreover, when $\Delta r a d 9 \operatorname{stn} 1-13$ double mutants were transferred back to $25^{\circ} \mathrm{C}$ after a $6-\mathrm{hr}$ shift to $37^{\circ} \mathrm{C}$, few cells were able to recover, whereas $R A D 9^{+} \operatorname{stn} 1-13$ and $M E C 3^{+} \operatorname{stn} 1-13$ cells recovered efficiently (data not shown). A similar loss of viability was observed in strain NGY359 following transfer back to galactose medium after exhaustion of Stn1 by growth on glucose medium.

From these two sets of experiments, we conclude that stn1-13 cells arrest at the restrictive temperature attributable to the presence of a functional $G_{2} / M$ checkpoint. Checkpoint-deficient stn1-13 cells progress through the cell cycle. However, they do so under inappropriate conditions, which apparently leads to cell death by mitotic catastrophe. Because cells with mutations in RAD 9 or $M E C 3$ that have not incurred DNA damage normally cycle without displaying loss of viability (Weinert and Hartwell 1993; Weinert et al. 1994), we infer that the stn1-13 mutation or depletion of Stn1 protein causes

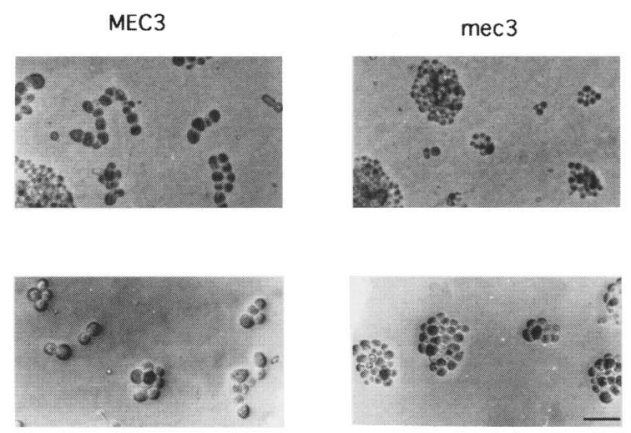

Figure 4. Cell cycle arrest attributable to STN1 loss of function depends on the DNA damage checkpoint. (Top) stn1 disrupted cells kept alive on galactose medium owing to production of Stn1 protein under GAL1 promoter control and bearing (mec3, right) or not (MEC3, left) a mutation in $M E C 3$, a DNA damage checkpoint gene, were streaked on glucose medium at $30^{\circ} \mathrm{C}$ and pictures taken after 3 days (mec3-2 is not temperature-sensitive). In the presence of the mec3 mutation (mec3, right), cells depleted for Stnl protein on glucose form numerous microcolonies, a phenotype indicative of a lack of cell cycle arrest by checkpoint control. Conversely, in checkpoint-proficient cells (MEC3, left), cells stop progression through the cell cycle. Such cells enlarge because they remain alive and continue to grow while arrested (MEC3, left). (Bottom) stn1-disrupted cells bearing the temperature-sensitive $\sin 1-13$ mutation and also bearing the wild-type $M E C 3$ gene (MEC3, left) or the mec3-2 mutant allele (mec3, right), were grown at $30^{\circ} \mathrm{C}$ on plates and transferred to $37^{\circ} \mathrm{C}$ for $6 \mathrm{hr}$ before pictures were taken. As above, the loss of STN1 function resulted in the formation of microcolonies in the stn1-13 mec3-2 double mutant. On the other hand, $\mathrm{MEC3}^{+}$cells exhibited a cell cycle delay in $\mathrm{G}_{2}$ while continuing to grow. Bars, $10 \mu \mathrm{m}$.

DNA damage, which activates the DNA damage $G_{2} / M$ checkpoint.

The Stn1-13 mutant protein is defective in cdc13-1 rescue even at $30^{\circ} \mathrm{C}$

We then asked whether the $\operatorname{stn} 1-13$ mutation specifically affected Cdc13 activity. cdc13-1 mutant cells were transformed with a multicopy plasmid bearing the $\sin 1$ 13 mutant allele or the wild-type STN1 gene as a positive control, and grown at $25^{\circ} \mathrm{C}$ before being transferred to various temperatures. Surprisingly, YEp-stn1-13 was incapable of rescuing the $c d c 13-1$ mutation at $30^{\circ} \mathrm{C}$ or $32^{\circ} \mathrm{C}$, temperatures fully permissive for the $\sin 1-13$ allele and at which wild-type STN1 rescues cdc13-1 on a YEp plasmid (Fig. 5, top panell. However, when the stn113 mutant allele was expressed from a YEp-GAL plasmid, a fairly good rescue of $c d c 13-1$ was observed at $30^{\circ} \mathrm{C}$, a partial rescue was observed at $32^{\circ} \mathrm{C}$, whereas no rescue at all was observed at $34^{\circ} \mathrm{C}$ (Fig. 5, bottom panels). These data demonstrate that overexpressed Stn 1-13 mutant protein is clearly defective in its ability to suppress the $c d c 13-1$ mutation even at a temperature permissive for growth of stn1-13 mutant cells, but that at extreme levels of expression it can partially rescue the $c d c 13-1$ mutation. These results suggest that the Stn $1-13$ protein 
Figure 5. Overexpression of the $\operatorname{stn} 1-13$ mutant allele from a YEp plasmid does not plasmid rescues $c d c 13-1$ partially but less efficiently than overexpression of the STN1 wild-type allele (bottom). cdc13-1 YEp vector alone, $c d c 13-1$ YEp-STN1 and cdc13-1 YEp-stn1-13 strains were grown at $25^{\circ} \mathrm{C}$ and then spotted on glucose plates for one day at $30^{\circ} \mathrm{C}$. The three patches of cells in each row represent 10 -fold serial dilutions of the same culture. $c d c 13-1$ YEpGAL vector alone, cdc13-1 YEp-GALSTN1 and $c d c 13-1$ YEp-GAL-stn1-13 strains were grown in glucose medium at $25^{\circ} \mathrm{C}$ and then spotted on galactose plates for 2 days at the indicated temperatures. rescue $c d c 13-1$ (top) and from a YEp-GAL

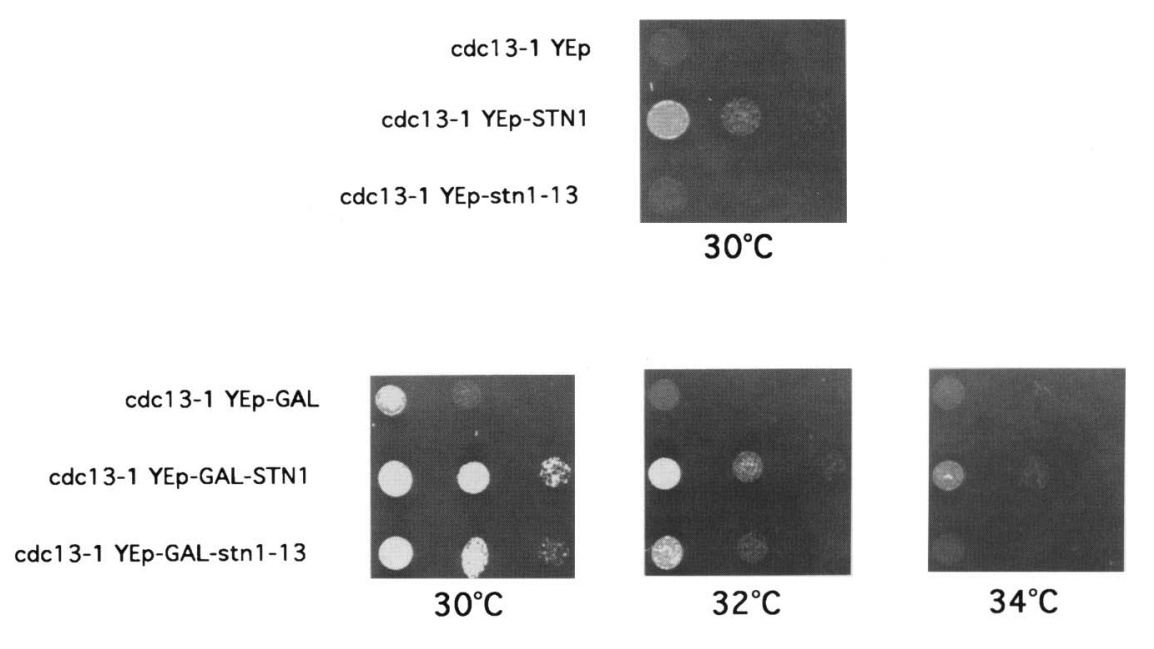

pressed alone was found to activate the system /data not shown). On the other hand, when $\mathrm{Cdc} 13$ and Stn 1 were co-expressed, a strong positive signal was generated, as judged by the rapid accumulation of $\beta$-galactosidase activity (intense blue color using X-gal within $1 \mathrm{hr}$; data not shown). Similarly, diploids formed following conjugation between Y187-pAS2-CDC13 and Y190-pACT2STN1 rapidly yielded an intense blue color in the X-gal assay, whereas the Y187/Y190 diploids coexpressing STN1 and CDC14 (or lamin or p53) displayed a white color (data not shown). The time of appearance of the blue color in the X-Gal assay in cells coexpressing STN1 and $C D C 13$ lagged behind that in cells co-expressing SNF1 and SNF4, used as positive standard controls (Fields and Song 1989), only by a few minutes ( $-40 \mathrm{~min}$ vs. $\sim 30 \mathrm{~min}$ ). This was confirmed by quantitative assays, using ONPG as a substrate, in which $\beta$-galactosidase activity was found to be 4.7 and $3.8 \mathrm{nmoles} / \mathrm{min}$ per $\mathrm{mil}$ ligram of protein, respectively, in cells co-expressing the Snf1/Snf4 and the Stn1/Cdc13 pairs.

The fact that STN1 partially rescued the $c d c 13-1$ mutation on a low-copy number plasmid, as well as the observation of a synthetic negative interaction between stn1-13 and cdc13-1 mutations, suggested that the two proteins Stn 1 and Cdc13 form a complex within the cell. In order to examine this possibility, both proteins were expressed simultaneously from plasmids used to detect protein-protein interactions in the yeast two-hybrid system (Fields and Song 1989; Durfee et al. 1993; Harper et al. 1993). Y187 or Y190 S. cerevisiae strains were transformed with pAS2-CDC13 or pACT2-STN1 plasmids (see Materials and Methods). Both constructs were functional as confirmed by complementation experiments. The pACT1-STN1 plasmid (pACT1 is identical in structure to pACT2), containing STN1 cDNA, was isolated by virtue of its capacity to complement the loss-of-function in an stn1 disruptant strain (see Materials and Methods). Moreover, the presence of pACT2-STN1 in stn1-13 cells completely suppressed their growth defect at $37^{\circ} \mathrm{C}$. Likewise, $c d c 13-1$ cells transformed with pAS2-CDC13 grew normally at the restrictive temperature of $37^{\circ} \mathrm{C}$ (data not shown). Neither Cdc13 nor Stn1 chimeras when ex- stn1-13 mutants, like cdc13-1 mutants, accumulate single-stranded DNA at telomeres

It was recently shown that $c d c 13-1$ mutants at restrictive temperature accumulate single-stranded DNA at telomeric and subtelomeric regions of the chromosomes (Garvik et al. 1995; Lydall and Weinert 1995). Similar analyses were conducted on $\operatorname{stn} 1-13$ mutants. DNA was prepared from either stn 1 mutants, $c d c 13$ mutants, or wild-type cells grown at $25^{\circ} \mathrm{C}$ and shifted at $37^{\circ} \mathrm{C}$ for 5 hr. DNA was prepared in such a manner that minimum of DNA breakage was generated (see Materials and Methods). Native DNA or denatured DNA was transferred and membranes incubated with a $\mathrm{Y}^{\prime}{ }^{32} \mathrm{P}$-labeled subtelomeric probe. The amount of hybridization to native DNA versus denatured DNA was measured. At $37^{\circ} \mathrm{C}$, stn 1-13 mutant cells accumulated single-stranded DNA in subtelomeric regions, although to a lesser extent than cdc13-1 mutant cells, an average of $4.0 \%$ and $17.3 \%$, respectively (Fig. 6). On the other hand, wild-type 


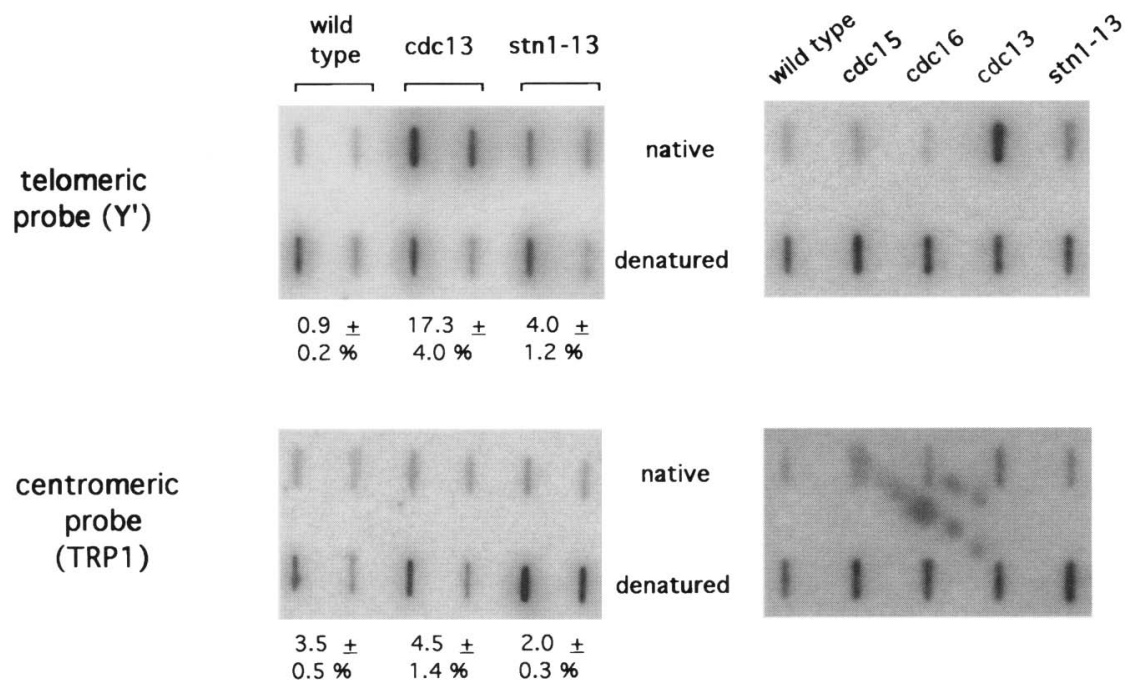

Figure 6. $\operatorname{stn} 1-13$ mutants, as well as cdc13-1 mutants, accumulate singlestranded DNA at telomeres. Cultures of YNG65 (wild-type), YNG32 (cdc13-1) and YNG429 (stn1-13) were grown to log phase at $25^{\circ} \mathrm{C}$ and transferred to $37^{\circ} \mathrm{C}$ for $5 \mathrm{hr}$. Native DNA and denatured DNA from these cultures were prepared as described in Materials and Methods. The percentage of single-stranded DNA indicated /for each sample, average and standard error from four independent experiments are shown) represents the amount of hybridization of native DNA to the DNA probe compared with the amount of hybridization measured in denatured DNA from the same sample. A $\mathrm{Y}^{\prime}$ probe, corresponding to sequences in subtelomeric regions of chromosomes, was used. Comparison of top left and bottom left panels shows that stn1-13 and cdc13-1 cells accumulate

single-stranded DNA in subtelomeric regions but not in centromeric regions of the chromosomes. Probe TRP1, which hybridizes to unique sequences close to the centromere of chromosome IV, was used. For each panel, the upper row corresponds to native DNA and the lower row to denatured DNA, as indicated. It is important to note that the amount of denatured DNA deposited in each slot is only $1 / 10$ of the amount of native DNA deposited. For each strain in top and bottom left panels, two concentrations of DNA (native or denatured) were deposited side by side, corresponding to 0.50 and $0.25 \mu \mathrm{g}$ of DNA (from left to right). (Top right) In contrast to stn1-13 and $c d c 13-1$ mutants, $c d c 15-2$ and $c d c 16-1$, respectively, late $\mathrm{M}$ and mid-M phase mutants, all at $37^{\circ} \mathrm{C}$ for $5 \mathrm{hr}$, did not accumulate single-stranded DNA in subtelomeric regions. (Bottom right) The control with the same strains using the centromeric probe. For each strain in top and bottom right panels, $0.50 \mu \mathrm{g}$ native DNA and $0.05 \mu \mathrm{g}$ denatured DNA were deposited in each slot.

cells had practically no single-stranded subtelomeric DNA (average of $0.9 \%$ ). When blots were probed with a centromeric probe (TRP1), no dramatic changes in the amounts of single-stranded DNA were detected in $c d c 13$ and $\operatorname{stn} 1$ mutant cells, as compared with control wildtype cells (Fig. 6).

To eliminate the possibility that single-stranded DNA accumulation was caused by cell cycle effects (wild-type cells continue to grow and cycle at $37^{\circ} \mathrm{C}$, whereas $c d c 13$ and $\operatorname{stn} 1$ cells arrest in $\mathrm{G}_{2}$ ), we also prepared genomic DNA from $c d c 15$ (arrest in late $M$ phase) and $c d c 16$ (arrest in mid-M phase) cells at $37^{\circ} \mathrm{C}$. The amounts of single-stranded DNA found in arrested $c d c 15$ and $c d c 16$ cells were identical to those found in wild-type cells (Fig. $6)$.

\section{Stn1 and Cdc13 regulate the size of telomeres}

Because the increased amount of single-stranded DNA in subtelomeric regions of $\operatorname{stn} 1-13$ and $c d c 13-1$ mutants suggested a role for these two genes in telomere metabolism, we measured the size of telomeres following a loss of function of STN1 or CDC13 or overexpression of these genes. To do this, genomic DNA of various strains was digested with $X$ hoI, which results in the release of chromosome extremities from a region located in the $\mathrm{Y}^{\prime}$ subtelomeric regions (Louis and Borts 1995). Digested DNAs were then detected on Southern blots by hybridization to radioactively labeled $\mathrm{TG}_{1-3}$ sequences (see Materials and Methods).

The significant conclusion of these experiments is that both $c d c 13-1$ and $\operatorname{stn} 1-13$ mutants display elongated telomeres. As shown in Figure 7 (left), both cdc13-1 cells grown at $29^{\circ} \mathrm{C}$ (maximal permissive temperature) for 40 generations and $\sin 1-13$ cells grown at $37^{\circ} \mathrm{C}$ (temperature allowing slow growth attributable to the leakiness of the mutation) for 40 generations contained lengthened telomeres compared with an isogenic wild-type strain. Lengthening of telomeres in these mutant strains was clearly visible by the appearance of DNA fragments migrating at $-2 \mathrm{~kb}$, corresponding to an average increase of $0.9 \mathrm{~kb}$ of telomeric repeats. Lengthening of telomeres appeared quantitatively similar in $c d c 13-1$ cells at $29^{\circ} \mathrm{C}$ and $\operatorname{stn} 1-13$ cells at $37^{\circ} \mathrm{C}$. Importantly, at $25^{\circ} \mathrm{C} \sin 1-13$ cells displayed telomeres elongated to the same extent as at $37^{\circ} \mathrm{C}$ [Fig. 7 (left), cf. lanes 5 and 6]. In the same vein, telomere size was also larger in cdc13-1 cells at $25^{\circ} \mathrm{C}$ than in a wild-type congenic strain [Fig. 7, cf. lanes 2 and 3 (left) and lanes 2 and 3 (right)]. The $c d c 13-1$ strains used here and throughout this study were backcrossed five times against the wild-type genetic background used in our laboratories. Therefore, the fact that $c d c 13-1$ cells have longer telomeres than wild-type cells at permissive temperatures cannot be attributed to differences in telomere lengths in different genetic backgrounds. This was confirmed by the fact that cdc13-1 cells transformed with YEp-CDC13 and grown at $25^{\circ} \mathrm{C}$ for 20 generations had shorter telomeres than $c d c 13-1$ cells at $25^{\circ} \mathrm{C}$ /Fig. 7, right). The fact that telomere size in cdc13-1 YEpCDC13 cells did not return to wild-type size [Fig. 7 (right), cf. lanes 2, 3, and 4] probably reflects the progressive nature of telomere size regulation. Assuming a telo- 
Figure 7. $c d c 13-1$ and $\operatorname{stn} 1-13$ mutant cells display an increase in telomere size. Xhol-digested DNA samples were hybridized to a $\mathrm{TG}_{1-3}$ telomeric probe (see Materials and Methods). Xhol cuts in the $\mathrm{Y}^{\prime}$ fragment of chromosomes (Louis and Borts 1995) at $\sim 1.1$ $\mathrm{kb}$ from the end in our genetic background. Most chromosomes have a $\mathrm{Y}^{\prime}$ subtelomeric region and, therefore, the sizes of the fragments migrating around $1.1 \mathrm{~kb}$ are proportional to the sizes of telomeres. Some chromosomes do not have a $\mathrm{Y}^{\prime}$ region (Louis and Borts 1995). From these chromosomes, Xhol cutting typically generates the fragments clearly seen on the gels around 1.9, 2.3, 3.2, and $4 \mathrm{~kb}$ (arrowheads in lane 1 of left panel). (Left, lane 1) MW markers; (lane 2) isogenic wild-type (YNG65); (lane 3) cdc13-1 (YNG32) at $25^{\circ} \mathrm{C}$; (lane 4) cdc13-1 (YNG32), 40 generations at $29^{\circ} \mathrm{C}$; (lane 5) $\operatorname{stn} 1-13$ (YNG429) at $25^{\circ} \mathrm{C}$; (lane 6) $\operatorname{stn} 1-13$ (YNG429), 40 generations at $37^{\circ} \mathrm{C}$; (lane 7) YCp-GAL-CDC13 (YNG510), 40 generations in galactose medium; (lane 8) YEp-GAL-STN1 (YNG509), 40 generations in galactose medium. The lower arrowhead of lane 1 marks the migration of $X$ hoI-cut telomere fragments in wild-type cells, $-1.1 \mathrm{~kb}$. The small elongation of telomeres in cdc13-1 cells at $25^{\circ} \mathrm{C}$ is clearly visible in lane 2 not only from the increased size of the Xhol-cut telomeres (from 1.11 to $1.17 \mathrm{~kb}$ ) but also from the increased sizes of the four upper bands (marked by arrowheads in wild-type cells) corresponding to the migration of telomere fragments that do not contain $\mathrm{Y}^{\prime}$ sequences in their subtelomeric regions (see Louis and Borts 1995). (Right, lane 1) MW markers; (lane 2) isogenic wild-type (YNG65); (lane 3) $c d c 13-1$ (YNG32) at $25^{\circ} \mathrm{C}$; (lane 4) cdc13-1 transformed with YEp-CDC13 (YNG519), 20 generations at 25 ${ }^{\circ}$; (lane 5) MW markers; (lane 6) $c d c 13-1$ transformed with YEp-STN1 (YNG128) at 25 ${ }^{\circ}$; (lane 7) $c d c 13-1$ transformed with YEp-STN1 (YNG128), 40 generations at $29^{\circ} \mathrm{C}$.

mere length of $\sim 0.3 \mathrm{~kb}$ in wild-type cells, telomere length in $\operatorname{stn} 1-13$ cells at $25^{\circ} \mathrm{C}$ or $37^{\circ} \mathrm{C}$ and in cdc13-1 cells at $29^{\circ} \mathrm{C}$ was measured to be $-1.2 \mathrm{~kb}$, yielding a 0.9 -kb elongation, whereas elongation in $c d c 13-1$ cells at $25^{\circ} \mathrm{C}$ was around $0.06 \mathrm{~kb}$.

Interestingly, overexpression of STN1 in $c d c 13-1$ cells suppressed telomere elongation (Fig. 7, right). Therefore, in $c d c 13-1 \mathrm{YEp}-\mathrm{STN} 1$ cells grown at $25^{\circ} \mathrm{C}$ for 40 generations, telomere size was identical to that in a wild-type congenic strain [Fig. 7 (right), cf. lanes 2 and 6], smaller than in $c d c 13-1$ cells (Fig. 7 , right). At $29^{\circ} \mathrm{C}$, the effect of STN1 overexpression on telomere size in $c d c 13-1$ cells was dramatic, resulting in shortening by $\sim 1 \mathrm{~kb}$ [Fig. 7, cf. lane 4 (left) and lane 7 (right)]. Telomeres in cdc13-1 YEp-STN1 cells at $29^{\circ} \mathrm{C}$ were even slightly shorter than in a wild-type congenic strain [Fig. 7, cf. lanes 2 and 7 (right)] (see Discussion).

Strains containing the $\operatorname{stn} 1-13$ mutation reached telomere size equilibrium, as the extent of elongation $(\sim \mathrm{kb})$ was constant after several weeks of continuous culture in liquid medium at 25,30 , or $37^{\circ} \mathrm{C}$ (data not shown). In contrast, $c d c 13-1$ cells cultured for 2 weeks at $29^{\circ} \mathrm{C}$ continued to exhibit telomere elongation beyond the size shown in Figure 7 (40 generations). On Southern blots, cdc13-1 telomere sizes under such conditions were difficult to measure (because of a very smeary signal) but appeared to be around 3.0 to $4.0 \mathrm{~kb}$ long (data not shown). Whether telomere length in cdc13-1 cells eventually reaches an equilibrium at $29^{\circ} \mathrm{C}$ remains to be determined.

On the other hand, in a wild-type background, neither overexpression of $C D C 13$ from a centromeric plasmid under the control of the GAL1 promoter [Fig. 7 (left), lane 7], nor overexpression of STN1 from an episomal plasmid under the control of the GAL1 promoter [Fig. 7 (left), lane $8]$ had any detectable effect on telomere size.

These data strongly implicate both STN1 and CDC13 in telomere function and/or maintenance. Interestingly, however, the effects of these mutations on telomere length did not correlate quantitatively with their effects on the generation of subtelomeric single-stranded DNA noted above. Therefore, Figure 7, lanes 4 and 6 (left), which represent similar telomere sizes in $c d c 13-1$ at $29^{\circ} \mathrm{C}$ and $\operatorname{stn} 1-13$ at $37^{\circ} \mathrm{C}$, respectively, corresponded under the same growth conditions, to $17 \%$ and $4 \%$ of single-stranded DNA in subtelomeric regions, respectively, as seen above (subtelomeric single-stranded DNA in $\operatorname{stn} 1-13$ was not measured at $25^{\circ} \mathrm{C}$, but was $1.5 \%$ at $30^{\circ} \mathrm{Cl}$.

Finally, to rule out the possibility that the higher than normal amounts of single-stranded DNA in these mutants might artifactually affect the migration of XhoIdigested fragments in the teloblot experiments, we performed additional controls in which the DNA was denatured before separation in agarose gels, as explained in Materials and Methods. Under such conditions, all of the 
telomere lengthening effects of $\operatorname{stn} 1-13$ and $c d c 13-1 \mathrm{mu}-$ tations were observed, as described in Figure 7 where the samples were denatured only after migration on agarose gels (data not shown).

\section{Discussion}

In this report, we describe STN1, an essential gene of $S$. cerevisiae, identified as a suppressor of the cdc13-1 mutation. At their primary amino acid sequence level, neither Cdc13 (Garvik et al. 1995) nor Stn1 (present work) display homologies with proteins identified previously or even share consensus sequences with known motifs. The Stnl protein is most probably required during $S$ phase and failure to execute its function activates the MEC3- and RAD9-dependent $\mathrm{G}_{2} / \mathrm{M}$ checkpoints, conferring cell cycle arrest. Based on two-hybrid analysis, Stn1 and $\mathrm{Cdcl} 3$ interact physically and both proteins appear to be involved in the regulation of telomere length. We propose a model in which $\mathrm{Cdc} 13$ and Stnl are part of an alternatively active and inactive telomerase complex (Fig. 8).

\section{STN1 is a novel, essential, S-phase gene}

STN1 can be considered a cell division cycle gene because a loss-of-function mutation arrests cells with a uniform phenotype while metabolic growth continues, a characteristic shared by all $c d c$ mutants (Pringle and Hartwell 1981).

Three lines of evidence indicate that STN1 function is required during S phase. First, STN1 was isolated by virtue of its ability to rescue a deficiency in a function of $C D C 13$, a gene implicated at the end of S phase /Garvik et al. 1995). Second, a loss of STN1 function, either following Stn1 protein depletion in a STN1 disruptant or in a ts $\operatorname{stn} 1$ strain, activates the $R A D 9$ and MEC3-dependent $G_{2} / M$ checkpoints (Weinert et al. 1994). Third, reciprocal shift experiments with cell cycle inhibitors indicate that STN1 function is executed during late $S$ phase or $\mathrm{G}_{2}$.

\section{Stn1 and Cdc13 have a function in telomere maintenance}

STN1 was isolated as a low-copy suppressor of the cdc13-1 mutation at the semi-permissive temperature of $30^{\circ} \mathrm{C}$, but is, in fact, a multicopy suppressor of that mutation at more restrictive temperatures. Absence of rescue of the $C D C 13$ defect at $37^{\circ} \mathrm{C}$ suggests that a minimal level of $\mathrm{Cdcl} 3$ activity is required for an essential function, which cannot be bypassed by elevated levels of Stn1. This is compatible with the idea that Stn 1 and Cdc13 function as a complex, a hypothesis supported by the findings that they physically associate based on twohybrid analysis and that the cdc13-1 and $\operatorname{stn} 1-13$ mutations genetically interact (Fig. 2D).

In this study, we present evidence that loss of function of either STN1 or CDC13 produces a dramatic lengthening of telomeres, directly measured by hybridizing chro-

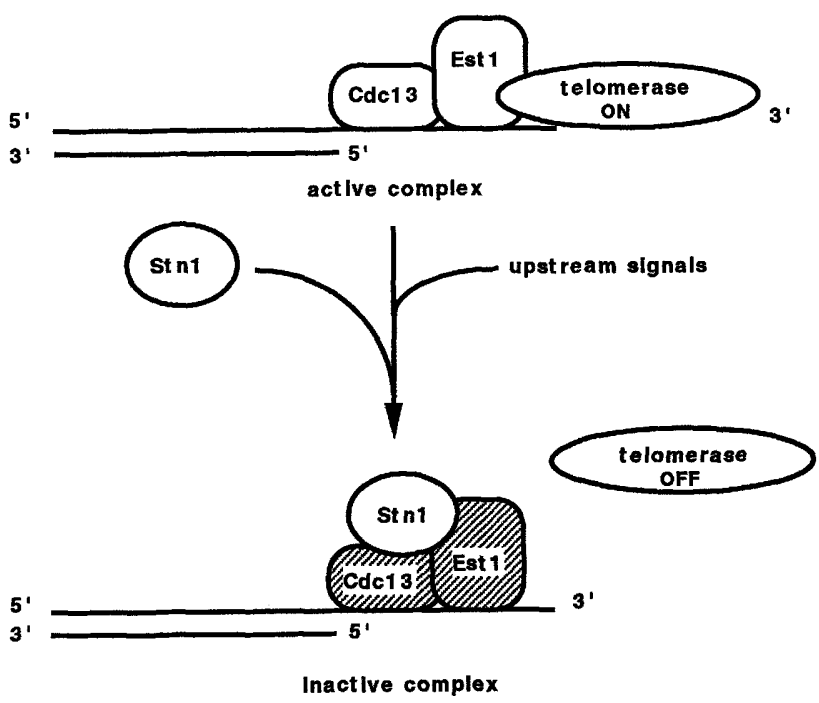

Figure 8. A model for regulation of telomerase by Stnl and Cdc13. (Top) An active telomerase complex, formed of telomerase, Est 1 and $\mathrm{Cdc} 13 . \mathrm{Cdc} 13$ is shown bound to the singlestrand G-rich extension present at the chromosome end, as proposed recently based on specific binding of $\mathrm{Cdcl} 3$ to singlestrand G-rich telomeric DNA and genetic interactions with Estl (Nugent et al. 1996). Est1 binds to the free $3^{\prime}$ terminus of the G-rich strand (Nugent et al. 1996) and to telomerase (Steiner et al. 1996). In this configuration, telomeres elongate. In response to a signal indicating the end of telomere elongation, when telomeres have reached a stasis (Rap1/Rif1 signaling pathway, e.g., Conrad et al. 1990; Lustig et al. 1990; Kyrion et al. 1992), Stn 1 binds to the active telomerase complex (or becomes active if already bound to the complex in an inactive form), inducing conformational changes in Est1 and/or in Cdc13, which lose the ability to recruit telomerase. As a result, telomere elongation terminates (see text for further explanations). In this model, the depiction of Stn1 and telomerase as being, reversibly, physically dissociated is speculative and it is equally possible that such a complex may be constitutive but reversibly active and inactive. Likewise, this schematic representation does not address the possibility of other proteins being part of the telomerase complex.

mosome ends with $\mathrm{TG}_{1-3}$ sequences. In addition, we have shown that $\operatorname{stn} 1-13$ cells exhibited an increased amount of single-stranded DNA in subtelomeric regions of the chromosomes at restrictive temperature, as has been shown recently for $c d c 13-1$ mutants (Garvik et al. 1995; Lydall and Weinert 1995). The amount of singlestranded DNA found here in a cdc13-1 strain at $37^{\circ} \mathrm{C}$ (average of $17 \%$, vs. $0.95 \%$ in wild-type cells) was much higher than that reported by Garvik et al. (1995) under identical conditions (average of $5 \%$ ). The discrepancy may be attributable to different genetic backgrounds used. In addition, the fact that $\operatorname{stn} 1-13$ cells display a smaller amount of single-stranded DNA (average of $4 \%$ ) than $c d c 13-1$ cells might be attributable to leakiness of the stn $1-13$ mutation. Alternatively, the difference might reflect different functions of the two proteins. In both $\operatorname{stn} 1-13$ and $c d c 13-1$ mutants, the increased percentage of single-stranded DNA in subtelomeric regions 
and telomere lengthening do not seem to correlate tightly. In stn1-13 cells for instance, the percentage of single-stranded DNA at the telomeres was $1.5 \%$ at $30^{\circ} \mathrm{C}$ and $4 \%$ at $37^{\circ} \mathrm{C}$, whereas telomeres were elongated to the same extent at either temperature. It should also be noted that each parameter (single-stranded DNA and telomere size) was measured under a variety of conditions, particularly at different intervals following the shift to the semi-permissive temperature.

Both the Cdc13-1 and Stn 1-13 mutant proteins conferred a defect in telomere maintenance. Lengthening of telomeres in $c d c 13-1$ cells at $25^{\circ} \mathrm{C}, \sim 0.06 \mathrm{~kb}$, was modest compared with that (nearly $1 \mathrm{~kb}$ ) in stn 1 mutants at $25^{\circ} \mathrm{C}$ or $37^{\circ} \mathrm{C}$, or in $c d c 13-1$ mutants at $29^{\circ} \mathrm{C}$ after 40 generations of growth. It may be that in contrast to the Stn 1-13 protein, which is defective at all temperatures, the Cdc13-1 protein displays a maximal defect only at elevated temperatures. However, it should be noted that the effect at permissive temperature, although modest, is significant because it was measured relative to a congenic strain. This was confirmed by reversal of telomere elongation in $c d c 13-1$ cells at $25^{\circ} \mathrm{C}$ following overexpression of CDC13. Moreover, telomere elongation in cdc13-1 cells was reversed by overexpression of STN1. This result is consistent with the idea that Stnl and Cdc13 form a codependent functional complex in vivo and that they participate in the same telomeric function. Both telomere elongation and the growth defect in cdc13-1 cells at $29^{\circ} \mathrm{C}$ could be suppressed by overexpressing STN1. However, it remains to be determined whether or not these two phenotypes of $c d c 13-1$ at $29^{\circ} \mathrm{C}$ are related.

stn1-13 mutant cells growing continuously at $25^{\circ} \mathrm{C}$ displayed the same lengthening of telomeres as cells growing for 40 generations at $37^{\circ} \mathrm{C}$, which strongly suggests a constant steady state length rather than a continuous lengthening of telomeres. This suggests that telomere size in stn1-13 mutant cells attains an equilibrium reminiscent of the situation in rap $1^{t}$ mutants (Kyrion et al. 1992). In contrast, cdc13-1 cells grown at their maximal permissive temperature, $29^{\circ} \mathrm{C}$, exhibited a continuous lengthening of telomeres. It is not known whether these cells eventually reach an equilibrium in telomere size or rather exhibit a continuous and progressive telomere lengthening. It is likely that an equilibrium in telomere size could be achieved independently of $\mathrm{Stn} 1 / \mathrm{Cdcl} 3$ function by alternative mechanisms of telomere length regulation, such as telomeric rapid deletion (Li and Lustig 1996). Increased telomere length is apparently not a lethal event because stn1-13 cells remain viable at temperatures (permissive or restrictive for growth) at which telomere elongation is observed. In contrast, mutations that promote continuous shortening of telomeres, such as est 1 or $t 1 c 1$, cause cell death (Lundblad and Szostak 1989; Singer and Gottschling 1994).

It has been speculated that Cdcl3 might be involved in the repair of single-stranded telomeric damage or in the protection of telomeric ends from degradation (Garvik et al. 1995). One suggested function for Cdc13 might be to regulate the size of a short $\mathrm{TG}_{1-3}$-containing telomeric sequence, the $\mathrm{TG}_{1-3}$ tail, which represents a normal intermediate in telomere replication (Garvik et al. 1995; Wellinger et al. 1996). Stn1 might form a complex with Cdc13 at the $\mathrm{TG}_{1-3}$ tails, the function of which would be to regulate the access of telomerase (see below) and of the putative $5^{\prime} \rightarrow 3^{\prime}$ exonuclease postulated by Wellinger et al. (1996) to have a role in $\mathrm{TG}_{1-3}$ tail size regulation. According to this hypothesis, Stn l/Cdc13 might function as the putative "cap" protein proposed to regulate telomere length in yeast (McEachern and Blackburn 1995).

\section{A model for Stn1 and Cdc13 function in telomere size control}

In a recent study, the isolation of a second mutant allele of CDC13, est 1-4, or cdc13-2 ${ }^{\text {est }}$, defective in telomere maintenance and therefore producing a progressive shortening of telomeres, was reported (Nugent et al. 1996). These authors also showed that Cdc13 specifically binds to single-strand G-rich telomeric DNA and that it genetically interacts with Est1. Because Est 1 protein associates with telomerase (Lin and Zakian 1995; Steiner et al. 1996), a Cdcl3-Estl complex might form at the single-stranded telomeric overhang to regulate telomerase activity (Nugent et al. 1996). Contrary to $c d c 13-2^{\text {est }}$ cells, cdc13-1 cells do not exhibit telomere shortening but, rather, display a modest telomere lengthening at $23^{\circ} \mathrm{C}$ (see Fig. 1 A, lanes 14 and 15, in Nugent et al. 1996; this study). The Cdc13-1 mutant protein could be defective in protection of the telomere end against degradation and the Cdc13-2 mutant protein defective in telomerase loading. This is based on the existence of a synthetic phenotype between $\Delta t l c 1$ and $c d c 13-1$ and on the absence of a genetic interaction between $\Delta t 1 c 1$ and $c d c 13-2^{\text {est }}$, as well as on the effect of $c d c 13-2$ and absence of an effect of $c d c 13-1$ on telomere size regulation (Nugent et al. 1996).

Because telomeres elongate in $\operatorname{stn} 1-13$ and $c d c 13-1$ mutants, Stn 1 and Cdc13 appear to act as negative regulators of telomerase activity. This is assuming that telomere elongation in these situations is attributable to telomerase-dependent events and not to recombination. On the other hand, the shortening of telomeres in $c d c 13$ $2^{\text {est }}$ mutants suggests that $\mathrm{Cdc13}$ is a positive regulator of telomerase activity (Nugent et al. 1996). The fact that overexpression of STN1 produces telomere shortening when Cdc13 is deregulated (in $c d c 13-1$ at $29^{\circ} \mathrm{C}$ ) (Fig. 7), presumably by binding too much of $\mathrm{Cdc} 13$ and decreasing its telomerase-loading activity, is consistent with this interpretation. Furthermore, the facts that Stnl and Cdc13 form a physical complex and that they genetically interact suggest that the inhibitory effect of Stnl operates through Cdc13. The cdc13-2 mutation specifically impairs binding between Cdc13-2 and Est1 (because overexpression of EST1 rescues $c d c 13-2$, but not $c d c 13-1$, see Nugent et al. 1996). Consequently, telomerase access is compromised and telomeres shorten (Nugent et al. 1996). Alternatively, Cdc13-2 might recruit Stn1 more efficiently, therefore increasing inhibition of the telom- 
erase complex. In the $c d c 13-1$ mutant, binding between Cdc13-1 and Stn1 is impaired /overexpression of STN1 rescues $c d c 13-1$, possibly by restoring wild-type levels of Stn $1 /$ Cdc13 complex). The telomerase complex consequently would remain in a predominantly active form and telomeres continue to elongate beyond normal size. In the stn1-13 mutant, binding between Stn1-13 and Cdc13 would also be affected (Stn1-13 mutant protein is defective in some function related to $\mathrm{Cdc13}$ because more Stn1-13 than Stn1 is required to rescue cdc13-1), but, presumably, to a lesser extent than binding between Stn 1 and Cdc13-1. This also results in failure to inhibit telomerase and telomere lengthening. Stn1-13 is presumably partially active as an inhibitor of telomerase access, as a new equilibrium in telomere size is achieved readily $(-0.9 \mathrm{~kb}$ longer than wild-type telomeres). Cdc13-1 is likely to be more defective in its capacity to recruit the putative telomerase inhibitor, Stn1, which is reflected by a failure of $c d c 13-1$ cells to rapidly attain a new equilibrium in telomere size at $29^{\circ} \mathrm{C}$.

Based on these observations, we propose that $\mathrm{Cdc} 13$ is alternatively a positive and negative regulator of telomerase activity. We further propose that $\operatorname{Stn} 1$ is a negative regulator of telomerase activity through its interaction with Cdc13. According to this model, a putative telomerase complex would be composed of at least Tlc1, Est1, Stn1, and Cdc13. Cdc13 would bind to the G-rich strand of telomeric DNA and to Estl (Fig. 8). Est1 would bind to the G-rich strand and to telomerase, therefore allowing telomeres to elongate. In response to a signal indicating sufficient telomere elongation, Stn1 would be recruited by $\mathrm{Cdcl3}$, therefore inhibiting the telomerase-loading activity of Cdc13 and/or Est1 (Fig. 8). It should be noted that Stn 1 might be present constitutively in the putative telomerase complex but in an inactive form, becoming active as an inhibitor periodically.

Deregulation of telomere size observed in $\sin 1-13$ and cdc13-1 mutants might be similar to that observed in some rap1 mutants (Conrad et al. 1990; Hardy et al. 1992; Kyrion et al. 1992; Moretti et al. 1994). In ter1 mutants affected in the telomerase RNA, the severity of deregulation of telomere length control has been shown to be directly proportional to the loss of Rapl binding to the mutated telomeric repeats (McEachern and Blackburn 1995; Krauskopf and Blackburn 1996). It is tempting to speculate that the Stn $1 / \mathrm{Cdc} 13$ complex might act in cooperation with Rapl in the control of telomerase accessibility to the $\mathrm{TG}_{1-3}$ tails via elongation of the $\mathrm{G}^{-}$ rich strand. This could be achieved either by association with the telomeric repeats at privileged sites or direct association with Rap1.

One can only speculate at the moment on the nature of the signals required for $\operatorname{Stn} 1$ and Cdc13 activities (Fig. 8 ). It should be noted that both genes are essential, whereas precise telomere size control is not essential and is not required at each cell cycle. The essential function of $\mathrm{Cdc13}$ may reside in its role of protection of the chromosome ends, as the damage caused by the $c d c 13-1$ mutation at restrictive temperature is lethal, at least when the cell cycle cannot be halted via the RAD9 sur- veillance system (Garvik et al. 1995). Therefore, Stn1 and Cdc13 activities (Fig. 8) must be required at each cell cycle and are likely to be controlled by cell cycle regulatory proteins. In this context, Stn 1 and/or Cdcl3 might mark the completion of $S$ phase and allow continuation of the cell cycle, a proposed function for $\mathrm{TG}_{1-3}$ tails (Wellinger et al. 1993). Upstream regulatory signals of Stn 1 and Cdc13 activities at the telomere other than cell cycle-dependent ones, might be signals controlled by the Rapl/Rif1 pathway (Conrad et al. 1990; Lustig et al. 1990; K;rion et al. 1992).

\section{Materials and methods}

Strains, media, genetic procedures, and growth conditions

Yeast strains used in this study were derivatives of BF26415Daub (ade1 his2 leu2-3,112 trp1-1a ura3Dns) (Richardson et al. 1989|, except for the strains used in the two-hybrid system. The $c d c 2, c d c 9, c d c 13$, and $c d c 17$ mutants were made isogenic by backcrossing several times with the parental wild-type strains (Table 1). All $c d c$ strains as well as the rad9::LEU2 strain were kindly provided by Leland Hartwell (University of Washington, Seattle, WA).

Yeast cultures were grown at the indicated temperatures in YEP (1\% yeast extract, 2\% Bacto-peptone, $0.005 \%$ adenine, $0.005 \%$ uracile) supplemented with $2 \%$ glucose (YEPD), sucrose or galactose, or in minimal medium (Sherman 1991). Induction of genes placed under the control of the GAL1 promoter was done by transferring cells growing in sucrose- or glucose-containing medium into galactose-containing medium after several washes when in liquid culture or by streaking cells from glucose-based plates onto galactose-based plates. For repression of the GAL1 promoter, cells growing in galactose-containing medium were also washed several times before transferring into glucose-containing medium.

Yeast genetic procedures were as described in Sherman et al. (1986). Gene disruption was performed as described by Rothstein (1983). Plasmids bearing the GAL1 promoter were constructed by cloning the GAL1 promoter into the EcoRI-BamHI sites of YCplac or YEplac plasmids (Gietz and Sugino 1988). All constructs were made by using PCR to adapt the relevant restriction sites to the sequence of the genes.

\section{Cloning and characterization of STN1}

cdc13-1 cells were transformed with a genomic library constructed in YCp50 (Rose et al. 1987) and plated onto uracillacking medium, at $25^{\circ} \mathrm{C}$. Colonies were then replica-plated at $30^{\circ} \mathrm{C}$ and $37^{\circ} \mathrm{C}$. Colonies that grew better than $\mathrm{cdc} 13$ at $30^{\circ} \mathrm{C}$ but did not grow at $37^{\circ} \mathrm{C}$ were selected. These colonies were transferred onto medium containing 5-fluoro-orotic acid (5-FOA, from PCR Inc.). Two colonies were selected that could no longer grow faster than the $c d c 13$ strain at $30^{\circ} \mathrm{C}$ in the presence of 5-FOA. Plasmids recovered from these two colonies contained the same $7-\mathrm{kb}$ insert. This insert was subcloned to find the smallest DNA fragment capable of rescue of $c d c 13$ at $30^{\circ} \mathrm{C}$. A 2.2-kb NruI/SacI insert was selected, transferred in pBS-KS and sequenced using the sequenase kit (Amersham). An ORF of 1482 bases was found that potentially encoded a 494-amino-acid protein. No splicing consensus sequences were found. The sequence corresponding to the ORF plus $200 \mathrm{bp}$ upstream (putative promoter) was amplified by PCR and, when cloned into single copy or multicopy plasmids, found to rescue $c d c 13$ at $30^{\circ} \mathrm{C}$. Moreover, to ascertain that the complete gene had been 
Grandin et al.

Table 1. Yeast strains

\begin{tabular}{|c|c|c|}
\hline Strains & Relevant genotype & Source \\
\hline NGY32 & MATa $c d c 13-1$ & this study \\
\hline NGY65 & MATa & $\begin{array}{l}\text { S. Reed (Scripps Research Institute, } \\
\text { La Jolla, CA) }\end{array}$ \\
\hline NGY66 & $M A T \alpha$ & $\begin{array}{l}\text { S. Reed (Scripps Research Institute, } \\
\text { La Jolla, CA) }\end{array}$ \\
\hline NGY104 & MATa rad9::LEU2 & this study \\
\hline NGY112 & MATa cdc 13-1 rad9::LEU2 & this study \\
\hline NGY123 & $M A T \mathbf{a} / M A T \alpha$ & this study \\
\hline NGY128 & MATa $c d c 13-1$ pSTN1 $(2 \mu, U R A 3)$ & this study \\
\hline NGY154 & MATa $c d c$ 13-1 pSTN1 (CEN, URA3) & this study \\
\hline NGY156 & MATa $c d c$ 13-1 pGAL ::STN1 (CEN, URA3) & this study \\
\hline NGY178 & $M A T \mathbf{a} c d c 17-1$ & this study \\
\hline NGY194 & MATa $c d c 13-1$ mec3-2 & $\begin{array}{l}\text { N. Grandin (Ecole Normale } \\
\text { Supérieure, Lyon, France) }\end{array}$ \\
\hline NGY203 & MATa $c d c 9-8$ & this study \\
\hline NGY238 & $M A T \mathbf{a} c d c 2-2$ & this study \\
\hline NGY291 & MATa $c d c 9-8$ pGAL ::STN1 $(2 \mu, U R A 3)$ & this study \\
\hline NGY293 & $M A T \mathbf{a} c d c 2-2$ pGAL ::STN1 $(2 \mu, U R A 3)$ & this study \\
\hline NGY295 & MATa $c d c$ 13-1 pGAL::STN1 $(2 \mu$, URA3) & this study \\
\hline NGY338 & $M A T a / M A T \alpha S T N 1 / \operatorname{stn} 1:: T R P 1$ & this study \\
\hline NGY346 & MATa $\operatorname{stn} 1:: T R P 1$ pGAL::STN1 (CEN, URA3) & this study \\
\hline NGY356 & MATa mec 3-2 & $\begin{array}{l}\text { N. Grandin (Ecole Normale } \\
\text { Supérieure, Lyon, France) }\end{array}$ \\
\hline NGY359 & MATa $\operatorname{stn} 1:: T R P 1 \operatorname{rad} 9:: L E U 2$ pGAL::STN1 (CEN, URA3) & this study \\
\hline NGY391 & MATa $\operatorname{stn} 1:: T R P 1$ mec3 pGAL:: STN1 (CEN, URA3) & this study \\
\hline NGY396 & MATa $\operatorname{stn} 1:: T R P 1$ pGAL:: STN1 (CEN, LEU2) & this study \\
\hline NGY429 & MATa $\operatorname{stn} 1::$ TRP1 pstn1-13 (CEN, LEU2) & this study \\
\hline NGY447 & $M A T \mathbf{a} / M A T \alpha S T N 1 / \operatorname{stn} 1:: U R A 3$ & this study \\
\hline NGY451 & MATa $\operatorname{stn} 1:: T R P 1$ pstn 1-13 (CEN, LEU2) pCDC13 $(2 \mu, U R A 3)$ & this study \\
\hline NGY452 & MATa $\operatorname{stn} 1:: T R P 1$ pstn1-13 (CEN, LEU2) $c d c 13$ & this study \\
\hline NGY467 & MATa $\operatorname{stn} 1:: T R P 1$ pstn $1-13(\mathrm{CEN}$, LEU2) mec3 & this study \\
\hline NGY497 & MATa $c d c 14-1$ & this study \\
\hline NGY498 & MATa $c d c 14-1$ pGAL ::STN1 $(2 \mu, U R A 3)$ & this study \\
\hline NGY499 & MATa $c d c 15-2$ & this study \\
\hline NGY500 & $M A T \mathbf{a} c d c 15-2$ pGAL $:: S T N 1(2 \mu, U R A 3)$ & this study \\
\hline NGY506 & $M A T \mathbf{a} c d c 17-1$ pGAL :: STN1 $(2 \mu, U R A 3)$ & this study \\
\hline NGY509 & $M A T \mathbf{a}$ pGAL ::STN1 $(2 \mu, U R A 3)$ & this study \\
\hline NGY510 & MATa pGAL ::CDC13 (CEN, LEU2) & this study \\
\hline MCY102 & $M A T \mathbf{a} / M A T \alpha$ pGAL4(1-147)-CDC13 pGAL4(768-881)-STN1 & this study \\
\hline MCY 105 & MATa/MAT $\alpha$ pGAL4(768-881)-STN1 pGAL4(1-147)-p53 gene & this study \\
\hline MCY106 & $M A T \mathbf{a} / M A T \alpha$ pGAL4(768-881)-STN1 pGAL4(1-147)-lamin gene & this study \\
\hline MCY108 & $M A T \mathbf{a} / M A T \alpha$ pGAL4(768-881)-STN1 pGAL4(1-147)-CDC14 & $\begin{array}{l}\text { M. Charbonneau (Ecole Normale } \\
\text { Supérieure, Lyon, France) }\end{array}$ \\
\hline
\end{tabular}

isolated, a cDNA library (gift from S. Elledge, Baylor College of Medicine, Houston, TX) was used to complement the STN1 disruption (see below). A $\operatorname{stn} 1:: T R P 1$ strain, kept alive with a $U R A 3$ plasmid bearing wild-type STN1 under the control of the GAL1 promoter, was transformed with the cDNA library constructed in a LEU2 plasmid (pACT1). Grown-up cells were cultured for several generations on leucine-lacking medium and then plated on 5-FOA-containing medium. The first colony that appeared was picked and the LEU2 plasmid recovered. The insert was sequenced and the cDNA sequence found to encode the same ORF as the genomic STN1 DNA, therefore confirming the absence of intronic sequences. The cloned STN1 cDNA started $7 \mathrm{bp}$ before the translation initiating ATG and ended $134 \mathrm{bp}$ after the stop codon.

DNA sequences were analyzed by DNA Strider. Homology searches were carried out using the BLAST program (Altschul et al. 1990) at NCBI, NIH.

\section{STN1 disruption}

The STN1 entire ORF plus 200 bp upstream of the ATG was amplified by PCR and cloned into the $B a m H I$ site of a pBS-KS plasmid deleted of its EcoRI site. The construct was then digested with $N c o I$ and EcoRI, which released the first $840 \mathrm{bp}$ of the gene and a $0.8-\mathrm{kb}$ PCR fragment containing the TRP1 gene was cloned between the NcoI site and the EcoRI site of STN1.

Another disruption was made using the URA3 marker. The STN1 ORF plus $200 \mathrm{bp}$ upstream of the ATG was cloned at the $B a m H I$ site of pBS-KS, cut with NcoI/AflII, which released the 
first $559 \mathrm{bp}$ of the ORF, made blunt ended and religated to a $1.1-\mathrm{kb}$ blunt ended URA3-containing fragment.

Both of these constructs were then cut with BamHI in order to release the disrupted STN1 gene that was then used to transform a diploid wild-type strain. Both the $\operatorname{stn} 1:: T R P 1 / S T N 1$ strain and the $\operatorname{stn} 1:: U R A 3 / S T N 1$ strain were induced to sporulate and tetrads dissected. In each disruption, only two viable spores per tetrad were recovered and none of these spores were found to be $\operatorname{Trp}^{+}$in the case of the stn1::TRP1 disruption 152 tetrads dissected), or $\mathrm{Ura}^{+}$in the case of the $\operatorname{stn} 1:: U R A 3$ disruption (30 tetrads dissected), indicating the disruption of an essential gene. The two diploid strains were then transformed with a centromeric plasmid containing the LEU2 marker and STN1 gene under the control of its own promoter. The strains were again induced to sporulate and tetrads dissected. This time, $\mathrm{Trp}^{+}$spores were recovered from the $\sin 1:: T R P 1 / S T N 1$ diploid, which were also all $\mathrm{Leu}^{+}$, and $\mathrm{Ura}^{+}$spores were recovered from the $\operatorname{stn} 1:: U R A 3 / S T N 1$ strain, which were also all $\mathrm{Leu}^{+}$. This suggested that the disrupted gene was STN1.

Genomic DNA of the two diploid strains, stn1::TRP1/STN1 and $\operatorname{stn} 1:: U R A 3 / S T N 1$, was prepared and disruption at the STN1 locus was checked by PCR (for both $\operatorname{stn} 1:: T R P 1$ and $\operatorname{stn} 1:: U R A 3$ ) and Southern analysis (for $\operatorname{stn} 1:: T R P 1$ ).

\section{Construction of a temperature-sensitive allele of STN1}

The following oligonucleotides were used to amplify the entire STN1 ORF plus 300 bp upstream of the ATG and 134 bp downstream of the stop codon: 5'-CCGGTACCCGCGAACTAGTCACG-3' and 5'-CCGGATCCTAACGTCCTTATTTG-3' . Amplification was performed on a plasmid bearing an STN1-containing chromosomal fragment, under the following mutagenic conditions: $1 \mathrm{mM}$ dCTP, $1 \mathrm{~mm}$ dTTP, $0.2 \mathrm{~mm}$ dGTP, $0.2 \mathrm{~mm}$ dATP, $3 \mathrm{~mm} \mathrm{MgCl}_{2}, 0.5 \mathrm{mM} \mathrm{MnCl}_{2}$, in standard PCR buffer (GIBCO BRL) and using standard Taq polymerase (GIBCO-BRL, ref. 18038067). Following a 30-cycle amplification, the PCR product was cleaned and $1 / 25$ was used as a substrate for another round of amplification under the same mutagenic conditions. According to the gap repair method, the PCR product was cleaned and used directly to transform an $\sin 1:: T R P 1 \mathrm{YCp}-$ GAL-STN1-URA3 strain, together with a centromeric LEU2 plasmid (YCp111) made linear by digestion and carrying STN1 flanking regions at each extremity: region -300 to -2 (adenine of the $\mathrm{ATG}=$ position 0 ) at one end, and region +1528 to +2784 (thymine of the TAA stop codon is at position 1484 and poly (A) tail stops at position 1620 ) at the other end, making $299 \mathrm{bp}$ upstream of STN1 and 92 bp dowstream of STN1 available for homologous recombination with the STN1 PCR fragment.

Cells were plated onto leucine-lacking glucose-containing medium at $25^{\circ} \mathrm{C}$. Around 6,000 transformants grew up which were transferred to leucine-lacking glucose-containing liquid medium for 2 days and then plated on 5-FOA-containing medium at $25^{\circ} \mathrm{C}$ in order to force the loss of the YCp-GAL-STN1URA3 plasmid. Growing colonies were then replica-plated on YEPD medium at $37^{\circ} \mathrm{C}$ in order to screen for temperature-sensitive transformants.

One temperature-sensitive transformant was selected. The LEU2 plasmid carrying the mutated allele of STN1 was recovered from this strain and used to transform the stn $1:$ TRP1 YCpGAL-STN1-URA3 strain. After loss of the URA3 plasmid on 5-FOA, the cells, which were kept alive now only by the presence of the LEU2 plasmid, were found to be temperature-sensitive, indicating that the temperature-sensitive phenotype was linked to the mutated allele of STN1 carried by the LEU2 plasmid. This allele was called $\sin 1-13$ and the plasmid carrying it, pstn1-13. As expected, stn1::TRP1 pstn1-13 cells transformed with a centromeric plasmid carrying wild-type STN1 lost their temperature-sensitive phenotype.

\section{Block and release experiments}

Cells were grown in YEPD medium, at $25^{\circ} \mathrm{C}$ overnight, then diluted to have a logarithmically growing population and grown for two more generations before hydroxyurea, $0.4 \mathrm{M}$, or nocodazole, $15 \mu \mathrm{g} / \mathrm{ml}$, final concentrations, was added. Cells were treated for $2 \mathrm{hr}$ with hydroxyurea or nocodazole at $25^{\circ} \mathrm{C}$, then transferred for $1 \mathrm{hr}$, still in the presence of the drug, at $37^{\circ} \mathrm{C}$ or $30^{\circ} \mathrm{C}$. Cells were then washed by centrifugation and released at either $37^{\circ} \mathrm{C}$ or $30^{\circ} \mathrm{C}$ and samples were fixed at 15 -min intervals in $3.7 \%$ formaldehyde. Percentages of unbudded cells and of cells with small, medium or large buds were determined microscopically.

\section{Immunofluorescence}

Experiments of immunostaining of tubulin of mitotic spindles (using rat anti-tubulin, clone YOL1/34, from Sera-Lab) and simultaneous staining of nuclei with DAPI were conducted exactly as described in Pringle et al. (1991).

\section{Two-hybrid experiments}

The two-hybrid "kit" was kindly provided by Stephen J. Elledge. Experiments of protein-protein interactions using the two-hybrid system were performed as described previously (Fields and Song 1989; Durfee et al. 1993; Harper et al. 1993). STN1 ORF was cloned in-frame with the GAL4 activation domain (nucleotides 764-885) of pACT2 (pACT2 and pAS2 vectors have been described in Durfee et al. 1993) using an endogenous NcoI site at the $5^{\prime}$ end and a PCR-adapted BamHI site at the $3^{\prime}$ end. CDC13 ORF was cloned in-frame with the GAL4 DNA-binding domain (nucleotides 1-147) in pAS2 using two PCR-adapted restriction sites-an NcoI site at the $5^{\prime}$ end and a SmaI site at the $3^{\prime}$ end of the ORF. Both constructs were transformed into the Y190 (MATa gal4 gal80 his3 trp1-901 ade2-101 ura3-52 leu2-3,-112 URA3::GAL $\rightarrow$ IacZ, LYS2::GAL(UAS) $\rightarrow$ HIS3 $\mathrm{cyh}^{\mathrm{r}}$ ) and $\mathrm{Y} 187$ (MATa gal4 gal80 his3 trp1-901 ade2-101 ura3-52 leu2-3,-112 met $^{-}$URA3::GAL $\rightarrow$ lacZ) strains. The two strains Y190 pACT2-STN1 and Y190 pAS2-CDC13 were tested for $\beta$-galactosidase activity and found to be negative. Strains were then induced to mate, generating the Y190/Y187 pACT2-STN1/ pAS2-CDC13 diploid strain that was also tested for $\beta$-galactosidase activity, and found to be positive. $\beta$-Galactosidase activity was tested as described previously (Durfee et al. 1993; Harper et al. 1993) using X-gal (5-bromo-4-chloro-3-indolyl- $\beta$-D-galactopyranoside, from Sigma). Quantitation of $\beta$-galactosidase activity in strains expressing the different constructs was performed using the ONPG (2-nitrophenyl- $\beta$-D-galactopyranoside, from Boehringer) protocol (Rose and Botstein 1983).

\section{Detection of single-stranded DNA}

Genomic DNA was prepared as described for the preparation of DNA for 2D gel analysis of replication intermediates $(\mathrm{Wu}$ and Gilbert 1995). Fifty milliliters of cells were grown at $25^{\circ} \mathrm{C}$ and transferred, when in $\log$ phase of growth, to $37^{\circ} \mathrm{C}$ for $5 \mathrm{hr}$. Cells were then washed and resuspended in nuclear isolation buffer (NIB, 17\% glycerol, $50 \mathrm{~mm}$ MOPS, $150 \mathrm{~mm}$ potassium acetate, 2 $\mathrm{mM} \mathrm{MgCl}_{2}, 500 \mathrm{~mm}$ spermidine, $150 \mathrm{~mm}$ spermine, at $\mathrm{pH} 7.2$ ). Cells were broken by addition of $425-600 \mu \mathrm{m}$-diameter glass beads and vigorous vortexing. Broken cells were transferred to a new tube, pelleted at $6500 \mathrm{~g}$ at $4^{\circ} \mathrm{C}$ for $10 \mathrm{~min}$ and the pellet 
resuspended in $G_{2}$ Qiagen lysis buffer containing $200 \mu \mathrm{g} / \mathrm{ml}$ ribonuclease A (Sigma). The lysate was incubated at $37^{\circ} \mathrm{C}$ for 30 $\mathrm{min}$. Twenty microliters of proteinase $\mathrm{K}$ at $20 \mathrm{mg} / \mathrm{ml}$ was then added and the lysate incubated at $37^{\circ} \mathrm{C}$ for $60 \mathrm{~min}$ more. The lysate was then centrifuged at $6500 \mathrm{~g}$ at $4^{\circ} \mathrm{C}$ for $10 \mathrm{~min}$ and the supernatant loaded on a pre-equilibrated 20/G Qiagen column, and allowed to pass through by gravity flow. The column was washed, DNA eluted, precipitated with isopropanol and resuspended in TE (10 mM Tris-HCl, $1 \mathrm{~mm}$ EDTA at $\mathrm{pH} 8.0)$. We routinely obtained $40 \mu \mathrm{l}$ of genomic DNA at a concentration of $0.5 \mu \mathrm{g} / \mu \mathrm{l}$.

Slot blot analyses were then performed as described in Garvik et al. (1995). Briefly, for each slot, 1.00, 0.50, or $0.25 \mu$ g of native DNA was adjusted to $165 \mu \mathrm{l}$ with water. Fifteen microliters were removed and denatured at $65^{\circ} \mathrm{C}$ for $30 \mathrm{~min}$ in $0.2 \mathrm{M} \mathrm{NaOH}$. Native and denatured DNA were then adjusted to $300 \mu \mathrm{l}$ with $10 \times \mathrm{SCP}\left(1 \mathrm{M} \mathrm{NaCl}, 0.3 \mathrm{M} \mathrm{Na}_{2} \mathrm{HPO}_{4}, 0.02 \mathrm{M}\right.$ EDTA at pH 6.8$)$ and drawn through a Hybond $\mathrm{N}$ membrane (Amersham) using a GIBCO BRL Hybri-Slot manifold. DNA was linked to the membrane by UV exposure and membrane was pre-hybridized and then hybrididized in $0.5 \mathrm{M}$ sodium phosphate $(\mathrm{pH} 7.2), 1 \mathrm{~mm}$ EDTA, $7 \%$ SDS, $500 \mu \mathrm{g} / \mathrm{ml}$ salmon sperm DNA. Y' and TRP1 DNA probes were made using $\left[\alpha{ }^{32} \mathrm{P}\right] \mathrm{dCTP} 3000 \mathrm{Ci} / \mathrm{mm}$ (Redivue, Amersham) using Appligene nona primer kit. Hybridization was quantified with a Storm Molecular Dynamics Phosphorimager.

\section{Measurements of telomere lengths on teloblots}

cdc13-1 and $\operatorname{stn} 1-13$ cells were grown in liquid cultures for -40 generations at the maximum temperature permitting growth $\left(29^{\circ} \mathrm{C}\right.$ for $c d c 13-1,37^{\circ} \mathrm{C}$ for $\left.\operatorname{stn} 1-13\right)$. Wild-type cells bearing the CDC13 and STN1 genes on YCp-GAL plasmids were grown for 40 generations in galactose-based liquid medium. Genomic DNA was then prepared from these strains as described in Philippsen et al. (1991). DNA was then digested with XhoI to cut within the $\mathrm{Y}^{\prime}$ regions of chromosomes (Louis and Borts 1995) and DNA fragments separated in a $0.9 \%$ agarose gel (in TBE) run in TBE buffer overnight. After denaturation, DNA was transferred onto nitrocellulose membrane and immobilized by baking at $80^{\circ} \mathrm{C}$ for $1 \mathrm{hr}$, under vacuum (Ausubel et al. 1995). The membrane was then pre-hybridized in $6 \times \mathrm{SSC}, 0.1 \%$ SDS, $1 \%$ nonfat milk and hybridized with a $270 \mathrm{bp} \mathrm{TG}_{1_{-3}}{ }^{32} \mathrm{P}$-labeled probe. Control experiments in which DNA was denatured before separation of DNA fragments on agarose gels were performed to ensure that the higher percentage of single-stranded DNA in $\operatorname{stn} 1$ and $c d c 13$ cells versus that in wild-type cells was not affecting migration of the telomeres. In this case, DNA fragments after $X$ hol cutting were separated under denaturing conditions using a $1 \%$ agarose gel (in $\mathrm{H}_{2} \mathrm{O}$ ) run in $40 \mathrm{mM} \mathrm{NaOH}$, 2 mM EDTA.

\section{Acknowledgments}

We thank Eric Gilson, Stéphane Marcand, and Christine Brun for helpful discussion and comments and for help with the teloblot experiments. We also thank Leland Hartwell and Barbara Garvik for gifts of strains and for communicating the singlestranded DNA protocol before publication; Stephen Elledge for gifts of plasmids, strains, and cDNA library; and Daniel Gietz and Akio Sugino for the gift of plasmids. This work was supported by grants from the "Fondation pour la Recherche Médicale", the "Association pour la Recherche contre le Cancer" (grant no. 6162), the "Comités Départementaux de l'Ardèche, Drôme et Haute-Savoie de la Ligue Nationale contre le Cancer" to M.C. and the National Institutes of Health (grant GM38328) to S.I.R.

The publication costs of this article were defrayed in part by payment of page charges. This article must therefore be hereby marked "advertisement" in accordance with 18 USC section 1734 solely to indicate this fact.

\section{References}

Altschul, S.F., W. Gish, W. Miller, E.W. Myers, and D.J. Lipman. 1990. Basic local alignment search tool. I. Mol. Biol. 215: 403-410.

Ausubel, F.A., R. Brent, R.E. Kingston, D.D. Moore, J.G. Seidman, J.A. Smith, and K. Struhl, ed. 1995. Current protocols in molecular biology. John Wiley and Sons, New York, NY.

Boulet, S., M. Simon, G. Faye, G.A. Bauer, and P.M.J. Burgers. 1989. Structure and function of the Saccharomyces cerevisiae CDC2 gene encoding the large subunit of DNA polymerase III. EMBO I. 8: 1849-1854.

Brewer, B.J., J.D. Diller, K.L. Friedman, K.M. Kolor, M.K. Raghuraman, and W.L. Fangman. 1993. The topography of chromosome replication in yeast. Cold Spring Harbor Quant. Biol. 58: 425-433.

Carson, M.J. and L. Hartwell. 1985. CDC17: An essential gene that prevents telomere elongation in yeast. Cell 42: 249-257.

Conrad, M.N., J.H. Wright, A.J. Wolf, and V.A. Zakian. 1990. RAP1 protein interacts with yeast telomeres in vivo: Overproduction alters telomere structure and decreases chromosome stability. Cell 63: 739-750.

Durfee, T., K. Becherer, P.-L. Chen, S.-H. Yeh, Y. Yang, A.E. Kilburn, W.-H. Lee, and S.J. Elledge. 1993. The retinoblastoma protein associates with the protein phosphatase type I catalytic subunit. Genes \& Dev. 7: 555-569.

Ferguson, B.M. and W.L. Fangman. 1992. A position effect on the time of replication origin activation in yeast. Cell 68: 333-339.

Fields, S. and O. Song. 1989. A novel genetic system to detect protein-protein interactions. Nature 340: $245-246$.

Garvik, B., M. Carson, and L. Hartwell. 1995. Single-stranded DNA arising at telomeres in cdc13 mutants may constitute a specific signal for the RAD9 checkpoint. Mol. Cell. Biol. 15: 6128-6138.

Gietz, R.D. and A. Sugino. 1988. New yeast-Escherichia coli shuttle vectors constructed with in vitro mutagenized yeast genes lacking six-base pair restriction sites. Gene 74:527534.

Gilson, E. and S.M. Gasser. 1995. Repressor Activator Protein 1 and its ligands: Organising chromatin domains. Nucleic Acids Mol. Biol. 9: 308-327.

Gilson, E., T. Laroche, and S.M. Gasser. 1993. Telomeres and the functional architecture of the nucleus. Trends Cell Biol. 3: $128-134$.

Gottschling, D.E., O.M. Aparicio, B.L. Billington, and V.A. Zakian. 1990. Position effect at S. cerevisiae telomeres: Reversible repression of PolII transcription. Cell 63: 751-762.

Greider, C. 1995. Telomerase biochemistry and regulation. In Telomeres (ed. E. Blackburn and C. Greider), pp. 35-68. Cold Spring Harbor Laboratory Press, Cold Spring Harbor, NY.

Hardy, C.F., L. Sussel, and D. Shore. 1992. A Rapl-interacting protein involved in transcriptional silencing and telomere length regulation. Genes \& Dev. 6: 801-814.

Harper, J.W., G.R. Adami, N. Wei, K. Keyomarsi, and S.J. Elledge. 1993. The p21 Cdk-interacting protein Cipl is a potent inhibitor of $\mathrm{G} 1$ cyclin-dependent kinases. Cell 
75: 805-816.

Jacobs, C.W., A.E.M. Adams, P.J. Szaniszlo, and J.R. Pringle. 1988. Functions of microtubules in the Saccharomyces cerevisiae cell cycle. I. Cell Biol. 107: 1409-1426.

Johnston, L.H. and K.A. Nasmyth. 1978. Saccharomyces cerevisiae cell cycle mutant cdc9 is defective in DNA ligase. $\mathrm{Na}$ ture 274: 891-893.

Krauskopf, K. and E.H. Blackburn. 1996. Control of telomere growth by interactions of RAP1 with the most distal telomeric repeats. Nature 383: 354-357.

Kyrion, G., K.A. Boakye, and A.J. Lustig. 1992. C-terminal truncation of RAP1 results in the deregulation of telomere size, stability, and function in Saccharomyces cerevisiae. Mol. Cell. Biol. 12: 5159-5173.

Li, B. and A.J. Lustig. 1996. A novel mechanism for telomere size control in Saccharomyces cerevisiae. Genes \& Dev. 10: $1310-1326$.

Lin, J.J. and V.A. Zakian. 1995. An in vitro assay for Saccharomyces telomerase requires EST1. Cell 81: 1127-1135.

Louis, E.J. and R.H. Borts. 1995. A complete set of marked telomeres in Saccharomyces cerevisiae for physical mapping and cloning. Genetics 139: 125-136.

Lundblad, V. and J.W. Szostak. 1989. A mutant with a defect in telomere elongation leads to senescence in yeast. Cell 57: 633-643.

Lustig, A.J., S. Kurtz, and D. Shore. 1990. Involvement of the silencer and UAS binding protein RAP1 in regulation of telomere length. Science 250: 549-553.

Lydall, D. and T. Weinert. 1995. Yeast checkpoints genes in DNA damage processing: Implications for repair and arrest. Science 270: 1488-1491.

McClintock, B. 1941. The stability of broken ends of chromosomes in Zea mays. Genetics 26: 234-282.

McEachern, M.J. and E.H. Blackburn. 1995. Runaway telomere elongation caused by telomerase RNA gene mutations. $\mathrm{Na}$ ture 376: 403-409.

Moretti, P., K. Freeman, L. Coodly, and D. Shore. 1994. Evidence that a complex of SIR proteins interacts with the silencer and telomere-binding protein RAP1. Genes \& Dev. 8: 2257-2269.

Nugent, C.I., T.R. Hughes, N.F. Lue, and V. Lundblad. 1996. Cdc13p: A single-strand telomeric DNA-binding protein with a dual role in yeast telomere maintenance. Science 274: 249-252.

Philippsen, P., A. Stotz, and C. Scherf. 1991. DNA of Saccharomyces cerevisiae. In Guide to yeast genetics and molecular biology (ed. C. Guthrie and G.R. Fink), pp. 169-182. Academic Press, San Diego, CA.

Pringle, J.R. and L.H. Hartwell. 1981. The Saccharomyces cerevisiae cell cycle. In Molecular biology of the yeast Saccharomyces cerevisiae: Life and inheritance (ed. J.N. Strathern, E.W. Jones, and J.R. Broach), pp. 97-142. Cold Spring Harbor Laboratory, Cold Spring Harbor, NY.

Pringle, J.R., A.E.M. Adams, D.G. Drubin, and B.K. Haarer. 1991. Immunofluorescence methods for yeast. In Guide to yeast genetics and molecular biology (ed. C. Guthrie and G.R. Fink), pp. 565-602. Academic Press, San Diego, CA.

Richardson, H.D., C. Wittenberg, F. Cross, and S.I. Reed. 1989. An essential G1 function for cyclin-like proteins in yeast. Cell 59: 1227-1133.

Rose, M. and D. Botstein. 1983. Construction and use of gene fusions lacZ ( $\beta$-galactosidase) which are expressed in yeast. Methods Enzymol. 101: 167-180.

Rose, M.D., P. Novick, J.H. Thomas, D. Botstein, and G.R. Fink. 1987. A Saccharomyces cerevisiae genomic plasmid bank based on a centromere-containing shuttle vector. Gene
60: $237-243$.

Rothstein, R. 1983. One-step gene disruption in yeast. Methods Enzymol. 101: 202-211.

Sandell, L.L. and V.A. Zakian. 1992. Telomeric position effect in yeast. Trends Cell Biol. 2: 10-14.

- 1993. Loss of a yeast telomere: Arrest, recovery and chromosome loss. Cell 75: 729-739.

Sherman, F. 1991. Getting started with yeast. In Guide to yeast genetics and molecular biology (ed. C. Guthrie and G.R. Finkl, pp. 3-21. Academic Press Inc., San Diego, CA.

Sherman, F., G. Fink, and J.B. Hicks. 1986. Methods in yeast genetics. Cold Spring Harbor Laboratory Press, Cold Spring Harbor, NY.

Singer, M.S. and D.E. Gottschling. 1994. TLC1: Template RNA component of Saccharomyces cerevisiae telomerase. Science 266: 404-409.

Steiner, B.R., K. Hidaka, and B. Futcher. 1996. Association of the Estl protein with telomerase activity in yeast. Proc. Nat1. Acad. Sci. 93: 2817-2821.

Weinert, T.A. and L.H. Hartwell. 1988. The RAD9 gene controls the cell cycle response to DNA damage in Saccharomyces cerevisiae. Science 241: 317-322.

- 1993. Cell cycle arrest of cdc mutants and specificity of the RAD9 checkpoint. Genetics 134: 63-80.

Weinert, T.A., G.L. Kiser, and L.H. Hartwell. 1994. Mitotic chekpoints genes in budding yeast and the dependence of mitosis on DNA replication and repair. Genes \& Dev. 8: $652-665$.

Wellinger, R.J., K. Ethier, P. Labrecque, and V.A. Zakian. 1996. Evidence for a new step in telomere maintenance. Cell 85: 423-433.

Wellinger, R.J., A.J. Wolf, and V.A. Zakian. 1992. Use of nondenaturing Southern hybridization and two dimensional agarose gels to detect putative intermediates in telomere replication in Saccharomyces cerevisiae. Chromosoma 102: $S 150-S 156$

1993. Origin activation and formation of single-strand $\mathrm{TG}_{1-3}$ tails occur sequentially in late $S$ phase on a yeast linear plasmid. Mol. Cell. Biol. 13: 4057-4065.

Wu, J.R. and D.M. Gilbert. 1995. Rapid DNA preparation for 2D gel analysis of replication intermediates. Nucleic Acids Res. 23: 3997-3998.

Zakian, V.A. 1995a. Saccharomyces telomeres: Function, structure, and replication. In Telomeres (ed. E. Blackburn and C. Greider), pp. 107-137. Cold Spring Harbor Laboratory Press, Cold Spring Harbor, NY.

1995b. Telomeres: Beginning to understand the end. Science 270: 1601-1607. 


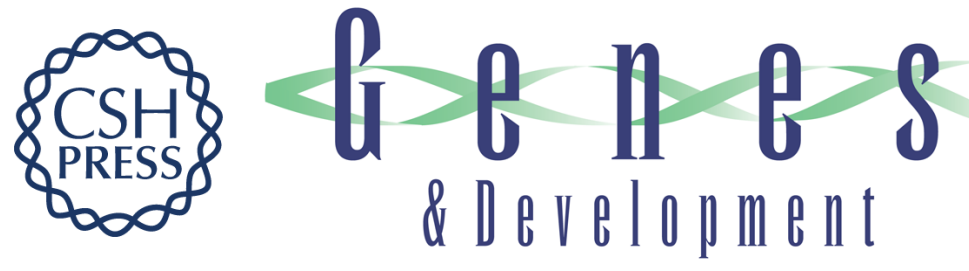

\section{Stn1, a new Saccharomyces cerevisiae protein, is implicated in telomere size regulation in association with Cdc13.}

N Grandin, S I Reed and M Charbonneau

Genes Dev. 1997, 11:

Access the most recent version at doi:10.1101/gad.11.4.512

References This article cites 45 articles, 20 of which can be accessed free at: http://genesdev.cshlp.org/content/11/4/512.full.html\#ref-list-1

License

Email Alerting

Service

Receive free email alerts when new articles cite this article - sign up in the box at the top right corner of the article or click here.

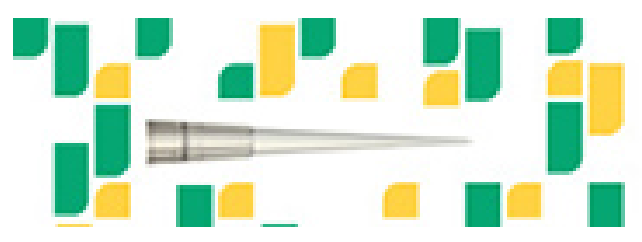

Focused on your science. 